\title{
Tracking climate variability in the western Mediterranean during the Late Holocene: a multiproxy approach
}

\author{
V. Nieto-Moreno ${ }^{1}$, F. Martínez-Ruiz ${ }^{1}$, S. Giralt ${ }^{2}$, F. Jiménez-Espejo ${ }^{1}$, D. Gallego-Torres ${ }^{1,3}$, M. Rodrigo-Gámiz ${ }^{1}$, \\ J. García-Orellana ${ }^{4}$, M. Ortega-Huertas ${ }^{3}$, and G. J. de Lange ${ }^{5}$ \\ ${ }^{1}$ Instituto Andaluz de Ciencias de la Tierra (CSIC-UGR), Avenida de las Palmeras no. 4, 18100 Armilla, Granada, Spain \\ ${ }^{2}$ Institute of Earth Sciences Jaume Almera (CSIC), Lluís Solé i Sabarís s/n, 08028 Barcelona, Spain \\ ${ }^{3}$ Departamento de Mineralogía y Petrología, Facultad de Ciencias, Universidad de Granada, Campus Fuentenueva s/n, \\ 18002 Granada, Spain \\ ${ }^{4}$ Departament de Física - Institut de Ciència i Tecnologia Ambientals (ICTA), Universitat Autònoma de Barcelona, \\ 08193 Bellaterra, Spain \\ ${ }^{5}$ Marine Geochemistry and Chemical Oceanography, Geosciences Faculty, Utrecht University, Budapestlaan 4, \\ 3584 CD Utrecht, The Netherlands
}

Received: 21 January 2011 - Published in Clim. Past Discuss.: 21 February 2011

Revised: 18 October 2011 - Accepted: 25 October 2011 - Published: 13 December 2011

\begin{abstract}
Climate variability in the western Mediterranean is reconstructed for the last $4000 \mathrm{yr}$ using marine sediments recovered in the west Algerian-Balearic Basin, near the Alboran Basin. Fluctuations in chemical and mineralogical sediment composition as well as grain size distribution are linked to fluvial-eolian oscillations, changes in redox conditions and paleocurrent intensity. Multivariate analyses allowed us to characterize three main groups of geochemical and mineralogical proxies determining the sedimentary record of this region. These three statistical groups were applied to reconstruct paleoclimate conditions at high resolution during the Late Holocene. An increase in riverine input (fluvial-derived elements - Rb/Al, Ba/Al, REE/Al, Si/Al, Ti/Al, $\mathrm{Mg} / \mathrm{Al}$ and $\mathrm{K} / \mathrm{Al}$ ratios), and a decrease in Saharan eolian input ( $\mathrm{Zr} / \mathrm{Al}$ ratio) depict the Roman Humid Period and the Little Ice Age, while drier environmental conditions are recognized during the Late Bronze Age-Iron Age, the Dark Ages and the Medieval Climate Anomaly. Additionally, faster bottom currents and more energetic hydrodynamic conditions for the former periods are evidenced by enhanced sortable silt (10$63 \mu \mathrm{m}$ ) and quartz content, and by better oxygenated bottom waters - as reflected by decreasing redox-sensitive elements (V/Al, $\mathrm{Cr} / \mathrm{Al}, \mathrm{Ni} / \mathrm{Al}$ and $\mathrm{Zn} / \mathrm{Al}$ ratios). In contrast, opposite paleoceanographic conditions are distinguished during the latter periods, i.e. the Late Bronze Age-Iron Age, the Dark Ages and the Medieval Climate Anomaly. Although no $\mathrm{Ba}$ excess was registered, other paleoproductivity indicators
\end{abstract}

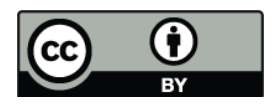

Correspondence to: V. Nieto-Moreno (vanesanieto@ugr.es) (total organic carbon content, $\mathrm{Br} / \mathrm{Al}$ ratio, and organometallic ligands such as $\mathrm{U}$ and $\mathrm{Cu}$ ) display the highest values during the Roman Humid Period, and together with increasing preservation of organic matter, this period exhibits by far the most intense productivity of the last $4000 \mathrm{yr}$. Fluctuations in detrital input into the basin as the main process managing deposition, reflected by the first eigenvector defined by the Principal Component Analyses, point to solar irradiance and the North Atlantic Oscillation variability as the main driving mechanisms behind natural climate variability over decadal to centennial time-scales for the last $4000 \mathrm{yr}$.

\section{Introduction}

Although more attention has been classically devoted to major climate changes during the last deglacial period (Heinrich stadial 1, Bølling-Allerød interstadial, and Younger Dryas) (e.g. Dansgaard et al., 1993; Magny et al., 2001; Stein et al., 2009), the Holocene is also punctuated by rapid climate variability, including polar cooling, aridity, and changes in the intensity of atmospheric circulation (Mayewski et al., 2004; Wanner et al., 2008). These climatic oscillations have been described in Greenland ice cores (e.g. O'Brien et al., 1995; Dawson et al., 2007), and in North Atlantic (e.g. Bond et al., 1997; Bianchi and McCave, 1999), Mediterranean (e.g. Casford et al., 2001; Rohling et al., 2009), Tropical Atlantic (e.g. deMenocal et al., 2000; Rimbu et al., 2004), and Antarctic deep sea cores (e.g. Masson et al., 2000; Bárcena et al., 2002); as well as in lake sediments (Magny, 2004; Jones et al., 2006), peat bogs (e.g. Blackford and Chambers, 1995),

Published by Copernicus Publications on behalf of the European Geosciences Union. 
speleothems (e.g. McDermott et al., 2001; Mangini et al., 2007), fossil pollen (e.g. Willard et al., 2005; Jalut et al., 2009) and tree rings (e.g. Esper et al., 2002; Moberg et al., 2005). Nevertheless, the overall lack of agreement about the worldwide distribution, precise timing, amplitude or cause of these fluctuations underlines the need for additional regional records to reconstruct climate change (e.g. Hughes and Diaz, 1994; Crowley and Lowery, 2000; Broecker, 2001).

At the global scale, natural external forcing - including solar irradiance variations and volcanic activity - have been highlighted as the main driving mechanisms of natural climate variability on centennial to millennial time-scales during the Holocene (e.g. van Geel et al., 1999; Crowley, 2000; Bond et al., 2001). At regional scales, patterns of natural internal climate variability such as El Niño-Southern Oscillation (ENSO) and the North Atlantic Oscillation (NAO) are known to vary over decadal to centennial time-scales (e.g. Jones et al., 2001; Turney and Palmer, 2007; Trouet et al., 2009). System response to multiple forcing and internal climate variability is further complicated by positive or negative feedback and non-linear responses, such as an interruption or weakening of the North Atlantic Deep Water (NADW) production rate during abrupt cold events (e.g. Bond et al., 1997; Bianchi et al., 1999). Besides the mechanisms underlying these natural climate fluctuations, Bond et al. (1997) describe several pervasive millennial scale North Atlantic cooling events (ice-rafted debris events) underway during the Holocene (with a mean pacing of $\sim 1500 \mathrm{yr}$; nearly the same as the Dansgaard/Oeschger events during the last glaciation), the Little Ice Age (LIA) being the most recent one.

Evidence of abrupt events at the millennial scale during the last glacial-interglacial transition have been previously reported in the westernmost Mediterranean (e.g. Cacho et al., 1999, 2001; Moreno et al., 2002, 2005; Bout-Roumazeilles et al., 2007; Jiménez-Espejo et al., 2007, 2008), revealing that this region is highly sensitive to climate forcing and provides ultra high-resolution records at both centennial and millennial scales. Abrupt decreases of paleo-sea surface temperatures and salinities in the Alboran Basin (e.g. Cacho et al., 1999; Bárcena et al., 2001; Melki et al., 2009), fresh polar-derived water flowing into the Mediterranean Sea through the Strait of Gibraltar (e.g. Sierro et al., 2005; Rogerson et al., 2010), intensification of north-westerly winds towards the Gulf of Lyon and thus enhanced Western Mediterranean Deep Water formation (WMDW) (e.g. Voelker et al., 2006; Frigola et al., 2008), continental dryness and reduction of the forest cover extent in the westernmost Mediterranean borderlands (e.g. Combourieu-Nebout et al., 2002; SánchezGoñi et al., 2002), and higher eolian input from the Saharan region (e.g. Moreno et al., 2005; Bout-Roumazeilles et al., 2007) have been correlated with cold spells taking place in the North Atlantic realm (Heinrich and Dansgaard/Oeschger stadials). Such findings support the linkage of this region with the North Atlantic coupled ocean-atmosphere system.
Despite the broad and intensive paleoenvironmental research performed in the western Mediterranean during the last few decades, high resolution marine records of the Late Holocene are comparatively scarce. The last $4000 \mathrm{yr}$ of this time interval are characterized by several climatic fluctuations, the best identified among them being the Late Bronze Age-Iron Age (LBA, 3600-2600 cal yr BP; van Geel et al., 1996), the Roman Humid Period (RHP, 2600-1600 cal yr BP; Issar, 2003), the Dark Ages (DA, 1600-1150 cal yr BP; Berglund, 2003), the Medieval Climate Anomaly (MCA, 1150-650 cal yr BP; Lamb, 1965; Hughes and Diaz, 1994) and the LIA (650-150 cal yr BP; Bradley and Jones, 1993). In this work we integrated data from two different marine records from the western Algerian-Balearic Basin. After high resolution analyses, they are compared with records from the Alboran Sea Basin. A multiproxy approach was adopted, featuring statistical characterization of the data sets, major and trace element-content fluctuations, grain size distribution, total organic carbon content (TOC) and mineral composition of marine sediments. This multiproxy approach allowed for the identification and characterization of the main climate oscillations and regional changes over the past $4000 \mathrm{yr}$, further advancing our understanding of natural climate variability in the westernmost Mediterranean.

\section{Climatological and oceanographic setting}

The Mediterranean climate is characterized by warm-hot dry summers and mild-cold wet winters due to the influence of the subtropical high-pressure belt and the mid-latitude westerly system (e.g. Lionello et al., 2006). During winter, the subtropical high reaches its southernmost position, allowing incursions of westerly winds that introduce mid-latitude cyclones from the Atlantic Ocean, resulting in a low intensity precipitation over the Mediterranean region. During summer, the subtropical high-pressure belt remains over this region, restraining precipitation and inducing climate dryness (e.g. Sumner et al., 2001; Bolle, 2003).

At decadal time-scales, the prevailing winter climate variability pattern in the North Atlantic region is the NAO (e.g. Hurrell, 1995; Trigo et al., 2004). The positive phase of the NAO is characterized by stronger than usual westerlies, tracing a pathway across middle latitudes farther to the north, and leading to dry and cold winters in southern $\mathrm{Eu}-$ rope, the Mediterranean, and northern Africa, and to warm and wet winters in northern Europe (e.g. Wanner et al., 2001; Trigo et al., 2002). Furthermore, enhanced dust transport from the Saharan region to the Mediterranean Sea has been evidenced during positive NAO phases (Moulin et al., 1997). The negative phase of the NAO is linked to opposite trends.

In terms of oceanographic conditions, the western Mediterranean Sea is characterized by a thermohaline circulation driven by excessive evaporation with respect to precipitation and runoff (e.g. Bethoux, 1979). Hence, the Atlantic 
jet stream becomes saltier and denser when it flows into the Mediterranean Sea (Modified Atlantic Water, MAW), and two anticyclonic gyres are produced when it progresses eastwards to the Algerian Basin (Western and Eastern Alboran Gyres) (e.g. Perkins et al., 1990; Millot, 1999). The MAW is offset by a deep-water outflow (Mediterranean Outflow Water; MOW) consisting of Levantine Intermediate Water (LIW) and WMDW, respectively originated in the Levantine Mediterranean Sea and in the Gulf of Lyon (e.g. Millot, 2008).

\section{Paleoenvironmental proxies: the mineralogical and geochemical record in the western Mediterranean Sea}

The detrital fraction of deep-sea sediments is a reliable proxy for paleoceanographic and paleoenvironmental reconstructions (e.g. Chamley, 1989) because it provides insight regarding the climate conditions prevailing in source areas and the mechanisms involved in the transport of material from land to sea (riverine and eolian input), as well as changes in the oceanic and atmospheric circulation that may trigger its dispersion (e.g. Bout-Roumazeilles et al., 2007; Fagel, 2007).

Previous studies of clay mineral composition in marine sediments from the western Mediterranean signal riverine input from the Iberian margin (e.g. Fabres et al., 2002) and wind-blown transport of particles from the African margin as the main sources of the detrital fraction (e.g. Guerzoni et al., 1997). Illite, chlorite and smectite are fluvial-derived, whereas kaolinite is considered reworked wind-blown particles from western Morocco and northern Algeria (e.g. BoutRoumazeilles et al., 2007).

Element/Al ratios (such as Rb/Al, REE/Al, Mg/Al, K/Al, $\mathrm{Si} / \mathrm{Al}, \mathrm{Ti} / \mathrm{Al}$ and $\mathrm{Zr} / \mathrm{Al}$ ) have also been studied to infer fluctuations in terrestrial run-off, erosional processes and riverine and eolian input to the Alboran Basin (e.g. Moreno et al., 2005; Jiménez-Espejo et al., 2008; Martín-Puertas et al., 2010). Aluminum-normalization is commonly used to envisage fluctuations in detrital aluminosilicate source material (e.g. van der Weijden, 2002). Rare earth elements (REE) are reliable indicators for tracing source provenance, as they are transferred nearly quantitatively in the terrigenous component through erosion and sedimentation (e.g. McLennan, 1989).

Meanwhile, redox-sensitive trace elements (such as V/Al, $\mathrm{Cr} / \mathrm{Al}, \mathrm{Ni} / \mathrm{Al}$ and $\mathrm{Zn} / \mathrm{Al}$ ) provide information about changes in bottom water oxygenation because their solubility depends on their valence, which in turn depends on the prevailing redox conditions (e.g. Martínez-Ruiz et al., 2003; Moreno et al., 2004; Jiménez-Espejo et al., 2007; Rogerson et al., 2008).

Approaches to correlate grain size to paleocurrent intensity refer to the percentage of sortable silt or coarse silt (SS, 10-63 $\mu \mathrm{m}$ ) as a proxy of relative paleocurrent speed (e.g. McCave et al., 1995; McCave and Hall, 2006). This proxy has been successfully applied in the western Iberian margin, showing that high SS values correlate with faster flows and better oxygenated deep waters (e.g. Hall and McCave, 2000). Thus, we have considered silt coarser than $10 \mu \mathrm{m}$ in the fine fraction as an indicator for paleocurrent speed equivalent to the UP10 index applied by Frigola et al. (2007) and Rogerson et al. (2008) in marine sediments from the western Mediterranean, rather than the sediment fraction susceptible to transport by wind as previously reported by Moreno et al. (2002).

\section{Materials and methods}

Two gravity-cores, $305 \mathrm{G} \quad\left(36^{\circ} 23.603^{\prime} \mathrm{N}, 1^{\circ} 22.710^{\prime} \mathrm{N}\right.$, $2512 \mathrm{mb}$ b.s.l. $)$ and $306 \mathrm{G}\left(36^{\circ} 27.846^{\prime} \mathrm{N}, 1^{\circ} 11.166^{\prime} \mathrm{W}\right.$, $2574 \mathrm{mb.s.1})$ - recovered during the Training-ThroughResearch Cruise 14 (TTR-14), Leg 2, in the west AlgerianBalearic Basin - were selected for this study (Fig. 1) (Comas and Ivanov, 2006).

Both cores were sampled in $1 \mathrm{~cm}$ thick slices to obtain a high resolution record for the last $4000 \mathrm{yr}$. Samples were treated to analyze chemical and mineralogical composition using different techniques. Bulk and clay mineral compositions were obtained by X-Ray Diffraction using a PANalytical X'Pert PRO diffractometer with $\mathrm{Cu}-\mathrm{K} \alpha$ radiation and automatic slit. Clay fraction separation and sample preparation was performed according to the international recommendations compiled by Kisch (1991). Diffractograms were visually interpreted using Xpowder software (Martin, 2004; http://www.xpowder.com). Peak areas were measured in order to estimate semiquantitative mineral contents, the estimated error being $<5 \%$ for bulk mineral composition and $5-10 \%$ for clay mineral proportions.

Quantitative geochemical microanalyses every five centimetres for clay mineral characterization were achieved by Transmission Electron Microscopy (HR-TEM; Philips CM20 provided with and EDAX microanalysis system). Additional morphological analyses of clays, barite and pyrite from selected samples were acquired by Field Emission Scanning Electron Microscopy (FE-SEM; LEO-Carl Zeiss-GEMINI1530). Barite was separated from eight selected samples with higher Ba content by a sequential leaching procedure (Eagle et al., 2003).

Major elements were measured using Wavelength Dispersive X-Ray Fluorescence Spectrometry (WDXRF; Bruker AXS S4 Pioneer with an Rh anode X-ray tube), using pressed pellets, with an analytical detection limit of $0.1 \%$ and an instrumental error $<1 \%$. Trace elements were analyzed by Inductively Coupled Plasma-Mass Spectrometry (ICP-MS; Perkin-Elmer Sciex Elan 5000) using Re and Rh as internal standards with an instrumental error of $\pm 2 \%$ and $\pm 5 \%$ for elemental concentrations of $50 \mathrm{ppm}$ and $5 \mathrm{ppm}$, respectively (Bea, 1996). Samples were prepared by sequential acid digestion $\left(\mathrm{HNO}_{3}+\mathrm{HF}\right)$ and measured in triplicate. REE values (La, Ce, Pr, Nd, Sm, Eu, Gd, Tb, Dy, Ho, Er, Tm, Yb, Lu) 
a)

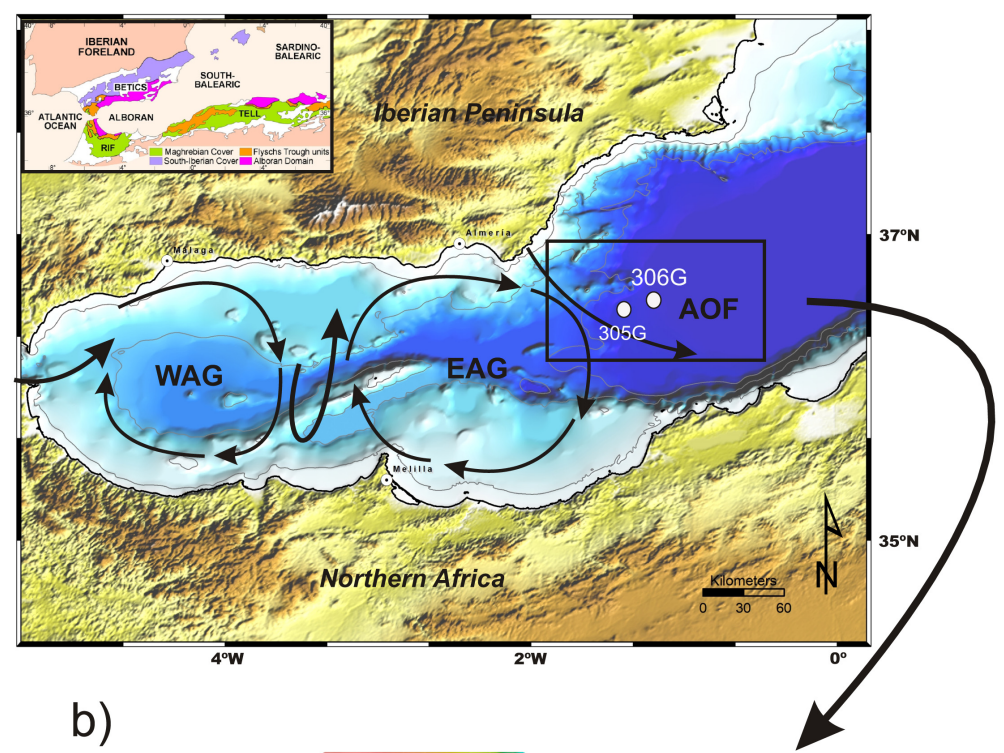

c)
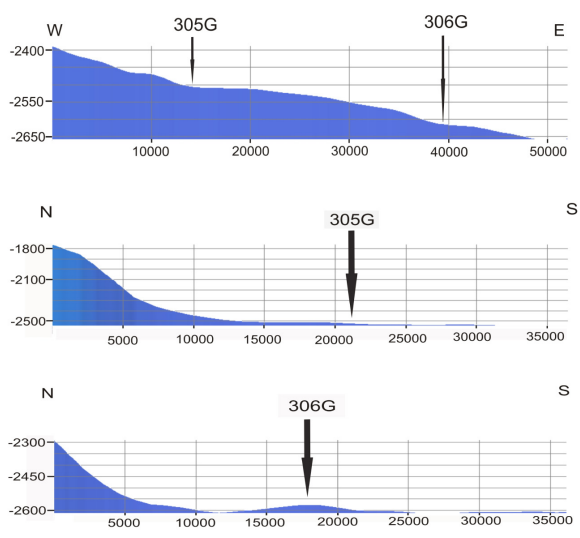

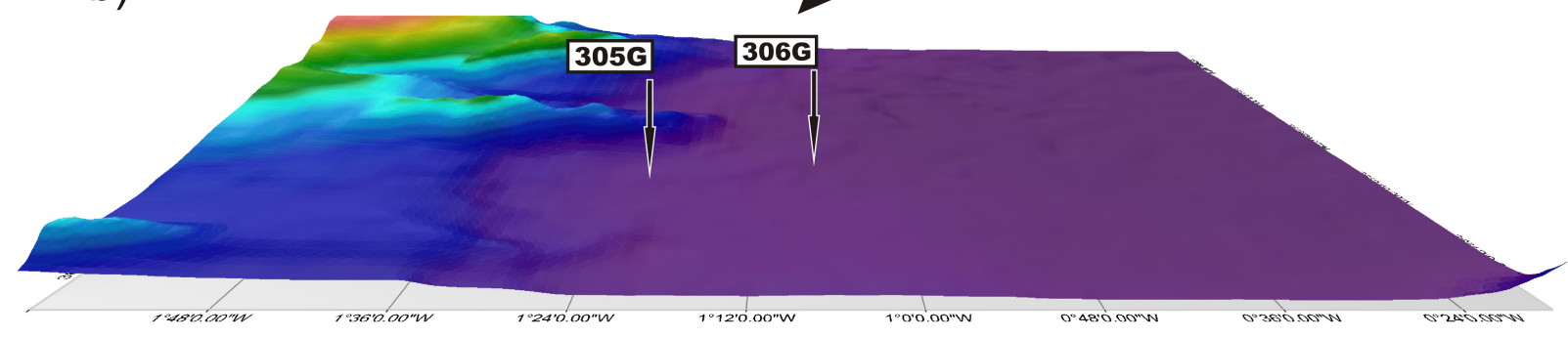

Fig. 1. (a) Site setting of the studied cores in the west Algerian-Balearic Basin (b) bathymetric map and (c) topographic profile showing the main physiographic features of the area under study. WAG: Western Alboran Gyre, EAG: Eastern Alboran Gyre, AOF: Almería-Orán Front.

were normalized with respect to CI chondrite according to McDonough and Sun (1995) with a resolution of five centimetres in both cores.

TOC content was determined using a Horiba EMIA-320V Series Carbon/Sulfur Analyzer. Grounded samples were subjected to acid leaching $(\mathrm{HCl})$ onto glass fiber filters in order to remove inorganic carbon. Treated samples were oxidized by the high-frequency induction furnace method under an oxygen stream, and $\mathrm{CO}_{2}$ gases evolved were detected by calibrated infra-red (IR) cells. TOC content was expressed as a percentage of dry weight. The accuracy of the method is $92 \%$, and precision is $0.01 \%$.

A granulometric study was undertaken on the bulk fraction at $2 \mathrm{~cm}$ intervals, taking away the coarse fraction $(>63 \mu \mathrm{m})$ by wet sieving and removing carbonates and organic matter from the remaining silt $(2-63 \mu \mathrm{m})$ and clay fraction $(<2 \mu \mathrm{m})$ by treatment with acetic acid (three times during $24 \mathrm{~h}$ each round, using $5 \mathrm{mll}^{-1}$ in the first acid attack and then $10 \mathrm{mll}^{-1}$ in the other two) and hydrogen peroxide (10\%, one week), respectively. Grain size was determined as a cumulative mass percentage using a Micromeritic Sedigraph III 5120, which measures particles ranging from
0.10 to $63 \mu \mathrm{m}$. Resolution and accuracy are, respectively, 1 and $0.1 \mu \mathrm{m}$. Two split fractions were established for the terrigenous silt: (a) fine silt $(2-10 \mu \mathrm{m})$, cohesive, mainly composed of clay minerals and settled as aggregated material, and (b) coarse silt (10-63 $\mu \mathrm{m})$ or sortable silt (SS), predominantly composed of quartz and feldspar and with noncohesive behaviour.

Statistical treatment of analytical data was performed using the statistical software package $\mathrm{R}$ (Development Core Team, 2011). Stratigraphically-constrained cluster analyses were applied to identify the main geochemical families and the outliers (isolated samples with anomalous values). The normalized geochemical dataset was also clustered in order to find groups of variables showing similar behaviour. The complete linkage method (or furthest neighbour method) was used for clustering purposes. Redundancy Analyses (RDA) were carried out on the geochemical and the mineralogical data set using the "vegan" package (Oksanen et al., 2009) to infer the relationship between them, and Principal Component Analyses (PCA) were performed on the geochemical data set to characterize the main underlying gradients governing the sedimentary environment. 

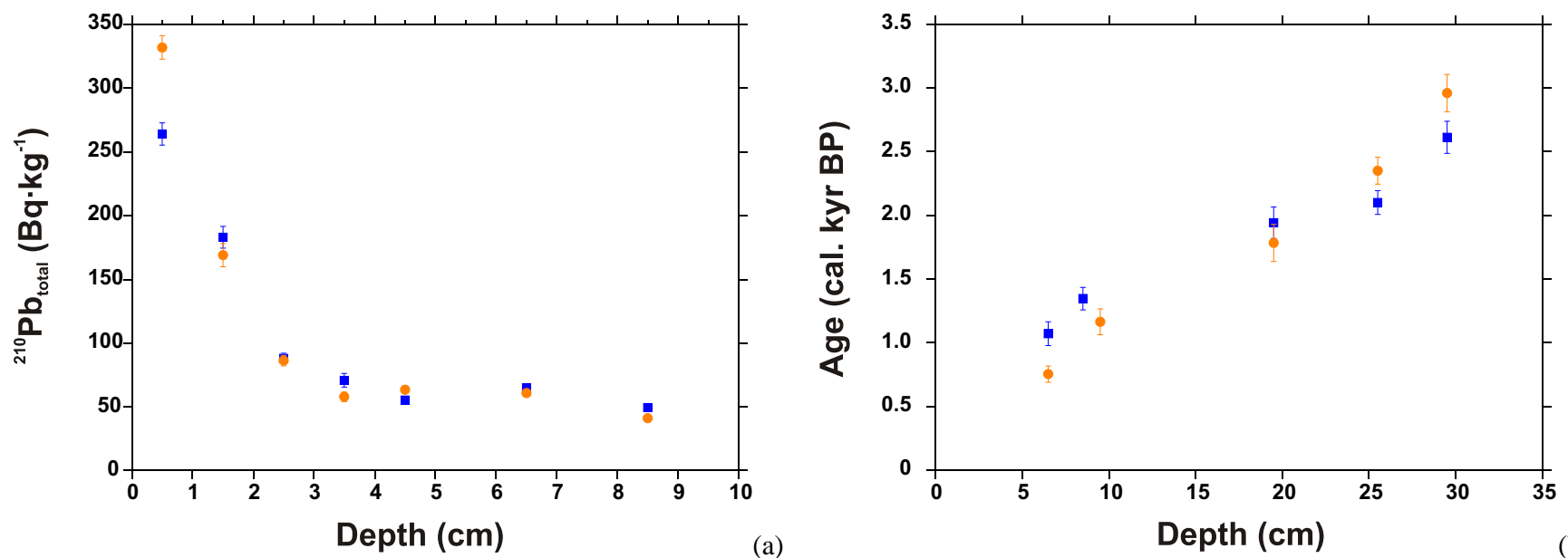

Fig. 2. Activity profiles of ${ }^{210} \mathrm{~Pb}_{\text {total }}\left(\mathrm{Bq} \mathrm{kg}^{-1}\right.$ ) for cores $305 \mathrm{G}$ (blue squares) and $306 \mathrm{G}$ (orange circles) with error bars representing $1 \sigma$ uncertainties (a) and ${ }^{14} \mathrm{C}$ dates for core $305 \mathrm{G}$ (blue squares) and 306 (orange circles) with error bars representing $2 \sigma$ uncertainties (b).

\section{Age-depth model and sedimentation rate}

The age-depth model is based on ${ }^{14} \mathrm{C}$ dating complemented with the activity-depth profiles of ${ }^{210} \mathrm{~Pb}$. Five ${ }^{14} \mathrm{C}$-AMS dates for each core were performed on monospecific planktonic foraminifera (Globigerina bulloides) extracted from the $>125 \mu \mathrm{m}$ fraction. Samples were analyzed by Accelerator Mass Spectrometry at the National Centre for Accelerators (CNA Spain) and the Poznan Radiocarbon Laboratory (Poland). Radiocarbon ages were calibrated to calendar years (cal BP) using CALIB 6.0 software (Stuiver and Reimer, 1993) and MARINE09 curve (Reimer et al., 2009), assuming a marine reservoir age correction of $400 \mathrm{yr}$ (Table 1). In order to obtain an age-depth model, a linear interpolation was applied between dates, giving mean sedimentation rates of 10.2 and $10.7 \mathrm{~cm} \mathrm{kyr}^{-1}$ for cores $305 \mathrm{G}$ and $306 \mathrm{G}$, respectively (Fig. 2b). Mean sedimentation rates and ${ }^{210} \mathrm{~Pb}$ inventories are similar to those reported in other deep Mediterranean areas by previous authors (García-Orellana et al., 2009).

${ }^{210} \mathrm{~Pb}$ was determined in the first five centimetres of both cores to obtain the most recent maximum sedimentation rates. Determination of ${ }^{210} \mathrm{~Pb}$ activities was accomplished through measurement of its daughter nuclide, ${ }^{210} \mathrm{Po}$, following the methodology described by Sánchez-Cabeza et al. (1998). Briefly, after addition of a given amount of ${ }^{209} \mathrm{Po}$ as the internal tracer, sediment aliquots of $200-300 \mathrm{mg}$ of each sample were totally dissolved in an acid medium using an analytical microwave oven. Polonium isotopes were plated onto pure silver discs in $\mathrm{HCl}(1 \mathrm{~N})$ at $70^{\circ} \mathrm{C}$ while stirring for $8 \mathrm{~h}$. Polonium emissions were subsequently counted with $\alpha$-spectrometers equipped with low-background silicon surface barrier detectors for $4 \times 10^{5} \mathrm{~s}$. Results showed that ${ }^{210} \mathrm{~Pb}$ was in excess only in the two first centimetres (Table 2). Although ${ }^{210} \mathrm{~Pb}$ inventories are similar to those reported in the Algerian-Balearic Basin (García-Orellana et al.,
Table 1. Radiocarbon dates and calibrated ages for cores $305 \mathrm{G}$ and 306G. Results are reported with a $2 \sigma$ uncertainty.

\begin{tabular}{lclcl}
\hline $\begin{array}{l}\text { Laboratory } \\
\text { code }\end{array}$ & Core & $\begin{array}{l}\text { Core } \\
\text { depth } \\
(\mathrm{cm})\end{array}$ & $\begin{array}{c}\text { Conventional } \\
\text { radiocarbon } \\
\text { age (BP) }\end{array}$ & $\begin{array}{l}\text { Calibrated } \\
\text { age } \\
\text { (cal BP })\end{array}$ \\
\hline Poz-37150 & 305G & $6-7$ & $1520 \pm 30$ & $1070 \pm 93$ \\
CNA567 & 305G & $8-9$ & $1795 \pm 40$ & $1346 \pm 88$ \\
CNA304 & $305 G$ & $19-20$ & $2320 \pm 45$ & $1942 \pm 124$ \\
Poz-37151 & $305 G$ & $25-26$ & $2335 \pm 30$ & $1956 \pm 94$ \\
CNA305 & $305 G$ & $29-30$ & $2870 \pm 45$ & $2613 \pm 126$ \\
Poz-37152 & $306 G$ & $6-7$ & $1130 \pm 35$ & $690.5 \pm 63.5$ \\
CNA306 & $306 G$ & $9-10$ & $1610 \pm 45$ & $1164 \pm 102$ \\
CNA307 & $306 G$ & $19-20$ & $2200 \pm 60$ & $1784 \pm 146$ \\
Poz-37153 & $306 G$ & $25-26$ & $2645 \pm 35$ & $2350 \pm 105$ \\
CNA308 & $306 G$ & $29-30$ & $3160 \pm 45$ & $2959 \pm 146$ \\
\hline
\end{tabular}

2009), they are lower than other sediment records from the area (Masqué et al., 2003), suggesting a loss of the surface part of the sediment during the gravity core recovery. Although some surface sediment loss is expected due to gravity core recovery, the enrichment of ${ }^{210} \mathrm{~Pb}$ in the first centimetres observed in both cores suggest that the loss of sediment is not significant, which is in agreement with the age model inferred from ${ }^{14} \mathrm{C}$-AMS dates (Fig. 2a).

\section{Statistical analyses: grouping proxies for paleoclimatic reconstruction}

The identification and characterization of the main processes behind sedimentary deposition in the study area were based on statistical analyses of the mineralogical and geochemical data sets. Normalized matrix clustering of the geochemical 
a)
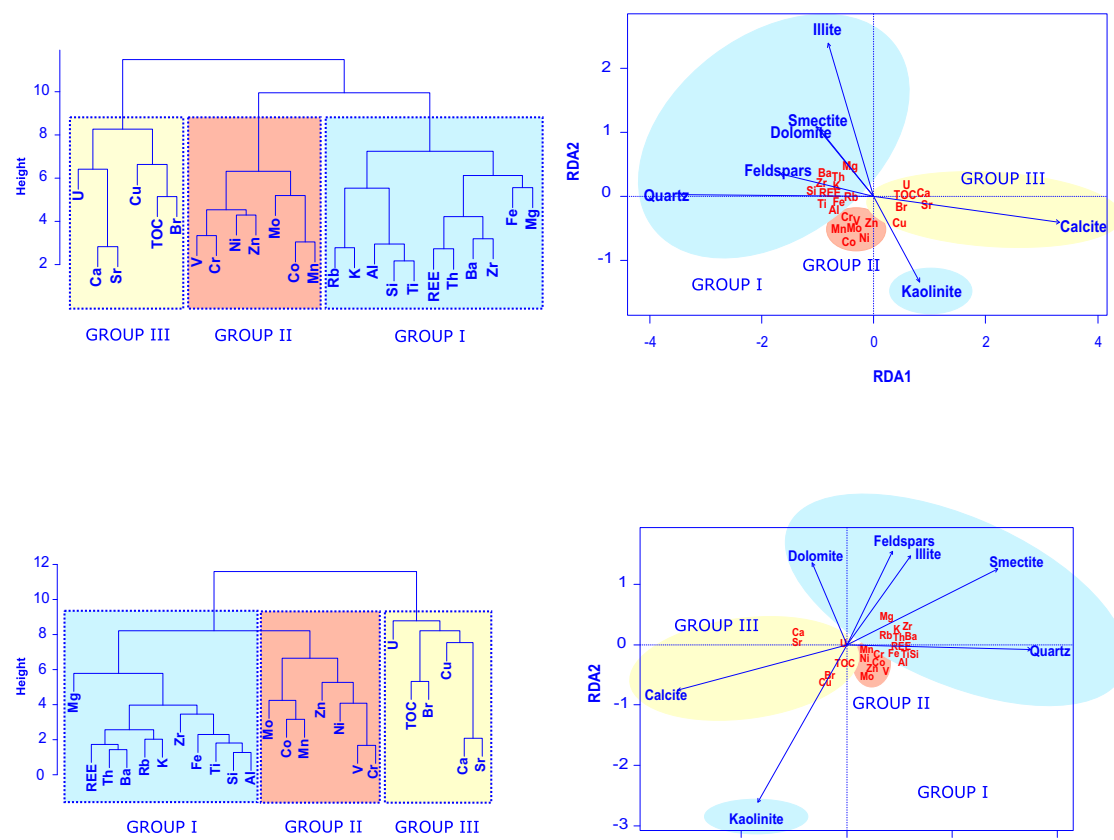

b) c)

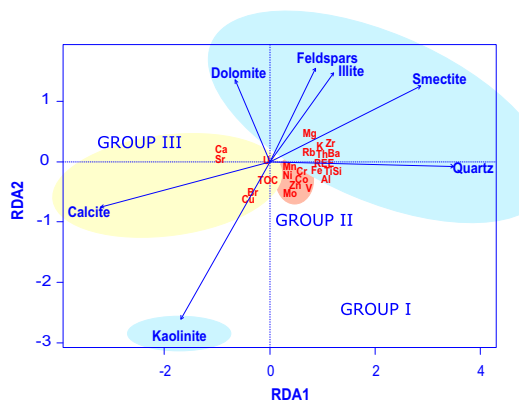

d) e)
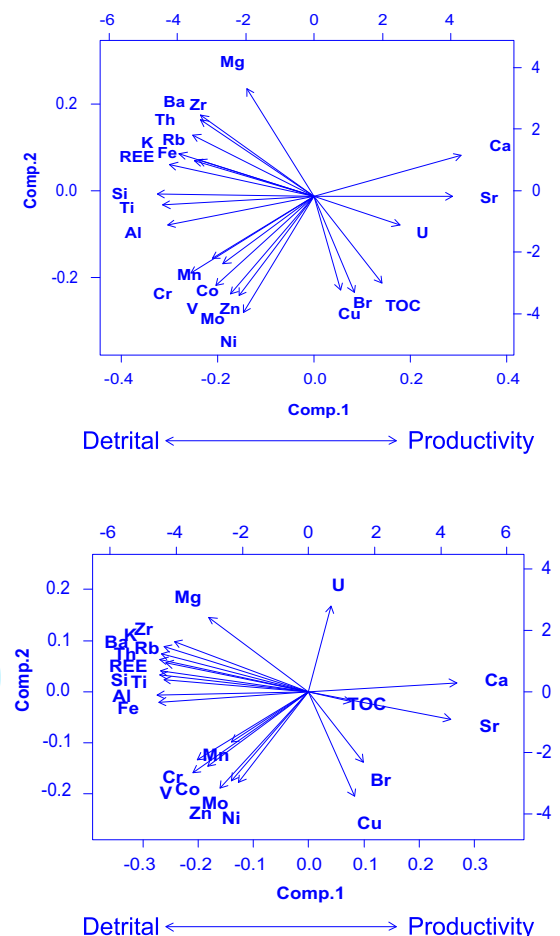

f)

Fig. 3. Statistical treatment of data from both sites. Cluster analyses of the geochemical data for sites $305 \mathrm{G}$ (a) and $306 \mathrm{G}$ (b), showing three main geochemical families in accordance to their affinity and origin. RDA biplots displaying the relationship between chemical elements and associated mineral phases for sites 305G (c) and 306G (d). Light yellow, orange and blue areas indicate Group I, II and III, respectively. Biplots showing the first and the second eigenvector defined by PCA for sites 305G (e) and 306G (f).

data (Fig. 3a and b) allowed us to identify the main geochemical families showing similar behaviour, and thus a high correlation in terms of their affinity and origin. RDA biplots illustrate the relationships between the chemical elements and their associated mineral phases. Three main groups in accordance with their origin in both sites were defined (Fig. 3c and d).

The first group comprises fluvial (illite, feldspars, smectite, dolomite, Al, Th, Rb, Ba, REE, Mg, K, Fe, Si and Ti) and eolian (kaolinite, Zr) derived elements/minerals (Fig. 3a-d). Fluvial-derived illite, smectite, feldspars and dolomite are opposed to eolian-derived kaolinite. Quartz appears in between detrital proxies of fluvial and eolian provenance, which suggests that it could come from both sources (e.g. Kolla et al., 1979) (Fig. 3c and d). Ba/Al and biogenic barite are widely used as paleoproductivity proxies in relation to episodes of enhanced productivity such as the Heinrich events (e.g. Moreno et al., 2004; Jiménez-Espejo et al., 2008). In this case, no $\mathrm{Ba}$ excess was registered and $\mathrm{Ba}$ is included in the first group. Hence, its association with alumino-silicates points to a detrital origin. Si and Ti have multiple hosts in marine sediments that vary considerably in particle size, ranging from clay to heavy minerals such as quartz or accessory Ti-bearing heavy minerals (e.g. Kolla et al., 1979; Calvert and Fontugne, 2001). Cluster and RDA analyses bound both elements to aluminium, thus revealing clay minerals as the most important hosts and riverine input as the main supply to the basin. REE show a high statistical significance with this detrital group in both cases (for cores 305G and 306G, respectively Th: $r^{2}=0.89$ and 0.96, $p<0.01$; Ba: $r^{2}=0.79$ and 0.96, $p<0.01$ ) (Fig. 3a and $b$ ), thus also revealing clay minerals as the most important hosts, while $\mathrm{Rb}$ is closely linked to $\mathrm{K}$ and to clay minerals (e.g. Horstman, 1957). The second group is composed of redox-sensitive elements including two sub-groups: those which are less soluble under reducing conditions and provide information on water oxygenation conditions $(\mathrm{V}, \mathrm{Cr}, \mathrm{Ni}$, $\mathrm{Zn}$ ), and those constituting insoluble oxy-hydroxides under oxic conditions $(\mathrm{Mn})$ and elements easily captured into them (Co, Mo). This second group is associated with the detrital one, pointing to alumino-silicates as main hosts. The third group contains paleoproductivity indicators associated with the organic flux, showing the high correlation between $\mathrm{Br}$ and marine organic matter, probably due to favoured uptake 
Table 2. Total ${ }^{210} \mathrm{~Pb}$ concentrations and ${ }^{210} \mathrm{~Pb}$ inventories for cores 305G and 306G. Results are reported with a $1 \sigma$ uncertainty.

\begin{tabular}{llll}
\hline $\begin{array}{l}\text { Laboratory } \\
\text { Code }\end{array}$ & Core & $\begin{array}{l}\text { Core } \\
\text { depth } \\
(\mathrm{cm})\end{array}$ & $\begin{array}{l}{ }^{210} \mathrm{~Pb}_{\text {total }} \\
\left(\mathrm{Bq} \mathrm{kg}^{-1}\right)\end{array}$ \\
\hline $305 \mathrm{G} 05$ & $305 \mathrm{G}$ & 0.50 & $264 \pm 9$ \\
$305 \mathrm{G} 15$ & $305 \mathrm{G}$ & 1.50 & $183 \pm 9$ \\
$305 \mathrm{G} 25$ & $305 \mathrm{G}$ & 2.50 & $88 \pm 4$ \\
$305 \mathrm{G} 35$ & $305 \mathrm{G}$ & 3.50 & $71 \pm 5$ \\
$305 \mathrm{G} 45$ & $305 \mathrm{G}$ & 4.50 & $55 \pm 3$ \\
$305 \mathrm{G} 65$ & $305 \mathrm{G}$ & 6.50 & $65 \pm 3$ \\
$305 \mathrm{G} 85$ & $305 \mathrm{G}$ & 8.50 & $49 \pm 3$ \\
$306 \mathrm{G} 05$ & $306 \mathrm{G}$ & 0.50 & $332 \pm 9$ \\
$306 \mathrm{G} 15$ & $306 \mathrm{G}$ & 1.50 & $169 \pm 9$ \\
$306 \mathrm{G} 25$ & $306 \mathrm{G}$ & 2.50 & $86 \pm 4$ \\
$306 \mathrm{G} 35$ & $306 \mathrm{G}$ & 3.50 & $58 \pm 4$ \\
$306 \mathrm{G} 45$ & $306 \mathrm{G}$ & 4.50 & $63 \pm 3$ \\
$306 \mathrm{G} 65$ & $306 \mathrm{G}$ & 6.50 & $61 \pm 3$ \\
$306 \mathrm{G} 85$ & $306 \mathrm{G}$ & 8.50 & $41 \pm 2$ \\
\hline${ }^{210} \mathrm{~Pb}{ }_{\text {base }}$ & $305 \mathrm{G}$ & & $57 \pm 8$ \\
${ }^{210} \mathrm{~Pb}\left(\mathrm{~Bq} \mathrm{~m}^{-2}\right)$ & $305 \mathrm{G}$ & & $1912 \pm 106$ \\
\hline${ }^{210} \mathrm{~Pb}$ base & $306 \mathrm{G}$ & & $56 \pm 10$ \\
${ }^{210} \mathrm{~Pb}\left(\mathrm{~Bq} \mathrm{~m}^{-2}\right)$ & $306 \mathrm{G}$ & & $2691 \pm 84$ \\
\hline
\end{tabular}

of bromine from seawater by marine plants (e.g. ten Haven et al., 1988; Ziegler et al., 2008). This provides a semiquantitative estimation of sedimentary organic matter. Although $\mathrm{U}$ and $\mathrm{Cu}$ are often used as redox-sensitive elements, cluster analyses show them to be associated with the cluster containing organic carbon and carbonates.

The first two eigenvectors of PCA account for $70 \%$ of the total variance at site $305 \mathrm{G}$ and for $73 \%$ at site $306 \mathrm{G}$. The first eigenvector represents $47 \%$ of the total variance at site $305 \mathrm{G}$ and $57 \%$ at site $306 \mathrm{G}$, and is mainly controlled by the detrital-productivity groups, whereas the second eigenvector represents $23 \%$ of the total variance at site $305 \mathrm{G}$ and $16 \%$ at site $306 \mathrm{G}$, and is mainly triggered by the water oxygenation conditions (Fig. $3 e$ and f). This result fits well with the differences in the location of these sites which may have resulted in different processes controlling sediment deposition. Site $305 \mathrm{G}$ is located at the continental slope (Fig. 1b and c) and is thus more affected by bottom currents and in turn, to changes in oxygen conditions. In contrast, site 306G is located in a more distal position in the abyssal plain on a small pelagic high, and is therefore more affected by detritalmarine productivity oscillations.

In light of these results, we applied the geochemical and mineralogical set of identified proxies to reconstruct paleoclimatic and paleoceanographic conditions including detrital input oscillations, marine productivity, oxygenation conditions and grain size distribution as well as post-depositional alteration during the last $4000 \mathrm{yr}$ in the western Mediterranean.

\section{Results and interpretation of the geochemical and the mineralogical record}

\subsection{Mineral composition and detrital input}

The analyzed sediments are predominantly composed of clay minerals (30-70\%), calcite (20-45\%) and quartz (10-30\%), with minor amounts of dolomite and feldspars $(<10 \%)$. Clay mineral assemblages consist of detrital mica (50-90\%), kaolinite + chlorite $(5-40 \%)$ and smectite $(<20 \%)$. Additional fibrous clay minerals, such as palygorskite and sepiolite, were identified using Transmission Electron Microscopy and Scanning Electron Microscopy, although their content quantified via X-Ray Diffraction ranges below instrumental error $(<5 \%)$, for which reason we did not consider them for the present study. These analyses verify that the smectite composition corresponds to Al-rich beidellites, indicating a detrital origin (chemical weathering) and a provenance from soils in the source areas (Martínez-Ruiz et al., 2003).

In both cases, REE values display an uniform pattern parallel to the average upper continental crust composition, with a typical variation consisting of slight L-REE enrichment relative to H-REE depletion and a negative Eu-anomaly, as well as values lower than the North American shale composite (NASC) and the Post-Archean Australian average shale (PAAS) (McLennan, 1989) (Fig. 4a and b).

At both sites, $\mathrm{Rb} / \mathrm{Al}, \mathrm{REE} / \mathrm{Al}, \mathrm{Ba} / \mathrm{Al}, \mathrm{Si} / \mathrm{Al}, \mathrm{Ti} / \mathrm{Al}, \mathrm{Mg} / \mathrm{Al}$, and $\mathrm{K} / \mathrm{Al}$ ratios show a similar general profile with slight differences (Fig. 5). Both cores exhibit a decreasing trend at $3600-1800,1600-1300$ and $1150-400$ cal yr BP, the trend less evident in the case of $\mathrm{Mg} / \mathrm{Al}$ and $\mathrm{K} / \mathrm{Al}$ ratios for core $306 \mathrm{G}$ at $3600-2800 \mathrm{cal}$ yr BP. An increase in these ratios is observed at $1800-1600$ and $1300-1150$ cal yr BP and from $400 \mathrm{cal}$ yr BP to present times. The $\mathrm{Zr} / \mathrm{Al}$ ratio gives relatively high values at 3600-2600, 1600-1300 and $1150-650$ cal yr BP and low values at 2600-1600 and 650150 cal yr BP.

\subsection{Grain size distribution, oxygen conditions, paleoproductivity indicators and post-depositional alteration}

The mean grain size ranges between $1-8$ and $0.5-10 \mu \mathrm{m}$ while the median grain size is $<2$ and $4 \mu \mathrm{m}$ at sites $305 \mathrm{G}$ and 306G, respectively (Fig. 7). The grain size distribution therefore consists mainly of clays and fine silts. Clays are most abundant at site $306 \mathrm{G}$ and fine silt at site $305 \mathrm{G}$, which fits well with the difference in location mentioned above (Fig. 1a). Site 306G, more influenced by detrital components, receives the finer fraction of the influx of the terrigenous component; at site $305 \mathrm{G}$, located at the continental slope and more affected by bottom currents, the coarser 

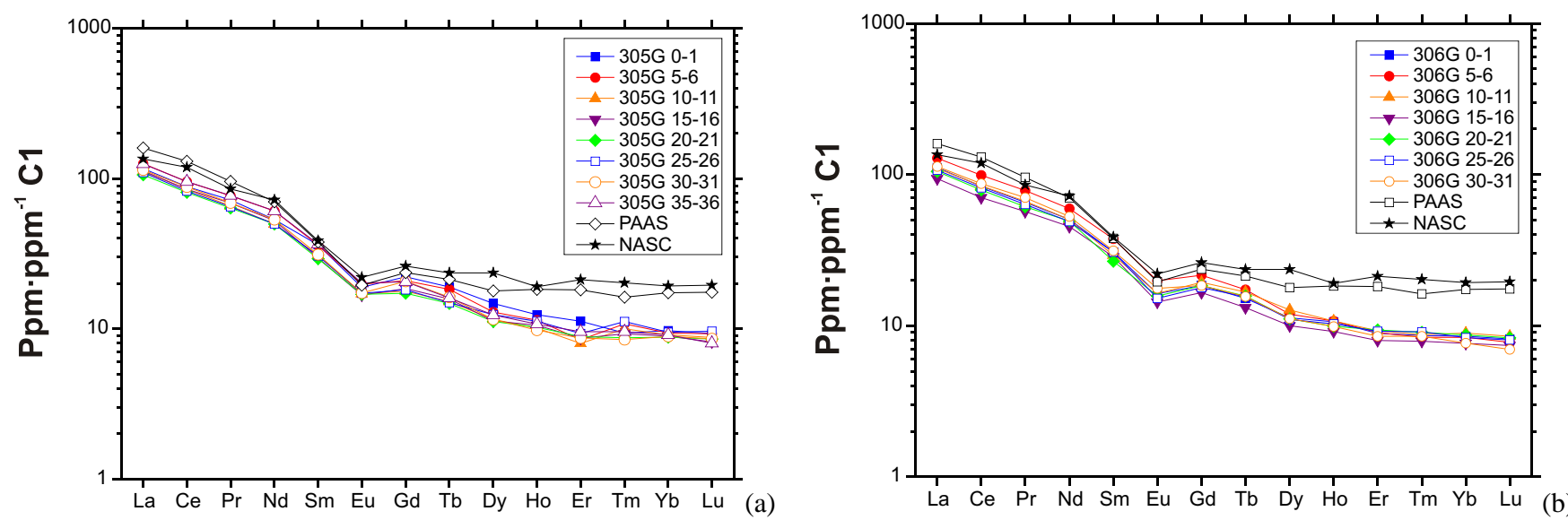

Fig. 4. CI chondrite-normalized REEs patterns ( $\mathrm{ppm} \mathrm{ppm}^{-1} \mathrm{CI}$ ) every five centimetres for cores $305 \mathrm{G}$ (a) and $306 \mathrm{G}$ (b) compared with the standard REE pattern of the NASC and the PAAS (McLennan, 1989).

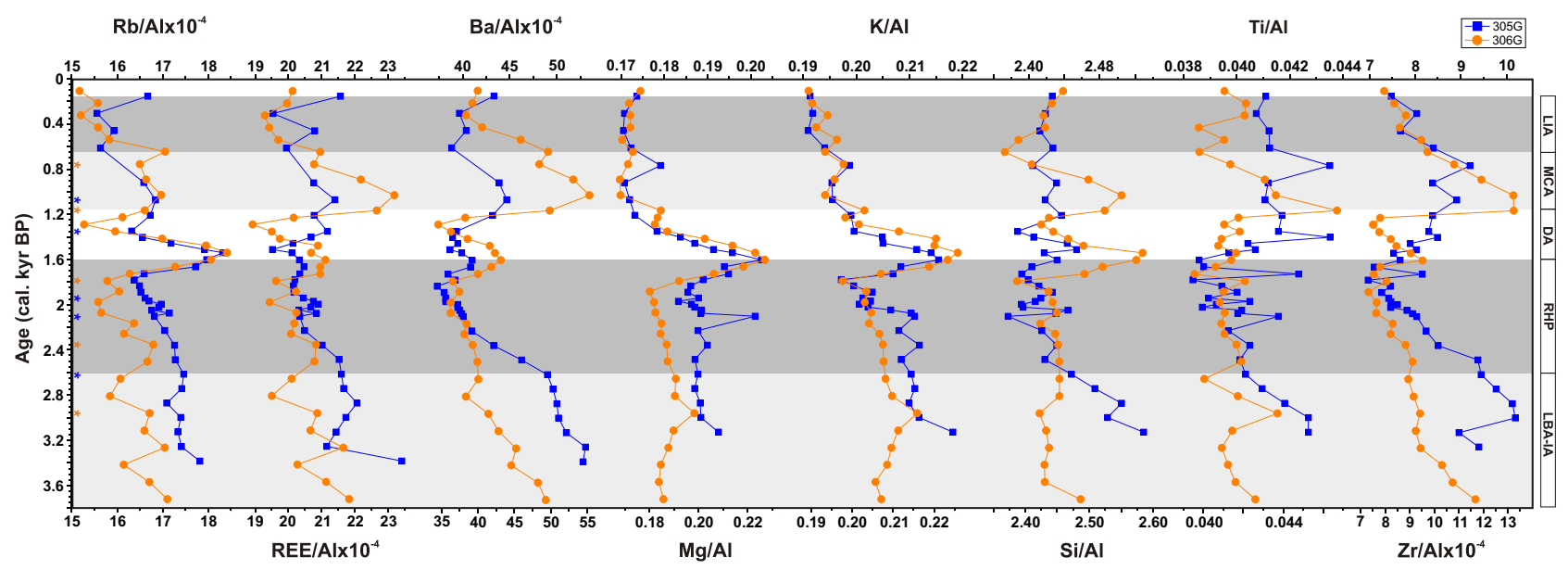

Fig. 5. Age-depth profile of detrital proxies (Rb/Al, REE/Al, Ba/Al and REE/Al $\times 10^{-4}$ ratios, $\mathrm{Si} / \mathrm{Al}, \mathrm{Ti} / \mathrm{Al}, \mathrm{Mg} / \mathrm{Al}$, and $\left.\mathrm{K} / \mathrm{Al} \mathrm{ratios}\right)$ for cores 305G (blue squares) and 306G (orange circles). Light grey bars indicate dry periods (MCA: Medieval Climate Anomaly, DA: Dark Ages, LBA-IA: Late Bronze Age-Iron Age); dark grey bars indicate humid periods (LIA: Little Ice Age, RHP: Roman Humid Period). Asterisks indicate the AMS ${ }^{14} \mathrm{C}$ dates.

sediments settle (Fig. 1b and c). Regarding SS values, a parallel trend is observed at the two sites, the peaks coinciding with increasing trends of the mean and the median distributions, and quartz content. These coarser sediments and higher quartz content occur at 3600-2200 cal yr BP, and at $1400-400 \mathrm{cal}$ yr BP, the exception being for core $306 \mathrm{G}$ at 3600-2200 cal yr BP, where finer grain size prevails and lower quartz content is found due to the fact that this site is less influenced by bottom currents.

At site $305 \mathrm{G}$, lower redox-sensitive elements contents (V/Al, Cr/Al, Ni/Al and Zn/Al ratios) (Fig. 8) coincide with coarser grain size sediment (Fig. 7) at 3600-2200 and $1400-400 \mathrm{cal}$ yr BP, and vice versa at $2200-1600 \mathrm{cal}$ yr BP and from $400 \mathrm{cal}$ yr BP onwards. Hence, oxygenated bottom waters percolating through the sediment are favoured by coarser grain size. This trend is mirrored by core $306 \mathrm{G}$, excluding the period 3600-2200 cal yr BP, when high values of redox-sensitive elements are observed, concurring with finer grain size and lower quartz content (Fig. 7).

TOC values are below $1 \%$ at both sites (Fig. 6). Although the general profile exhibits a progressive down-core decline, both cores display the highest values at 2000-1600 cal yr BP and at the top of the core. High TOC values also occur at $1150-650 \mathrm{cal}$ yr BP in core $306 \mathrm{G}$. Br/Al ratio achieves its maximum values during $2000-1600$ cal yr BP and at the top of the core at both sites. Br/Al ratio mainly mirrors the TOC content trend with the exception of the time interval $1150-650$ cal yr BP in core $306 \mathrm{G}$, when a preferential degradation of $\mathrm{Br}$ in relation to TOC takes place. U/Th displays a flat pattern at both sites, although this ratio increases at $2000-1600$ cal yr BP when maximum values are reached. The increase concludes around $1150 \mathrm{cal} \mathrm{yr} \mathrm{BP}$ at site $306 \mathrm{G}$ 


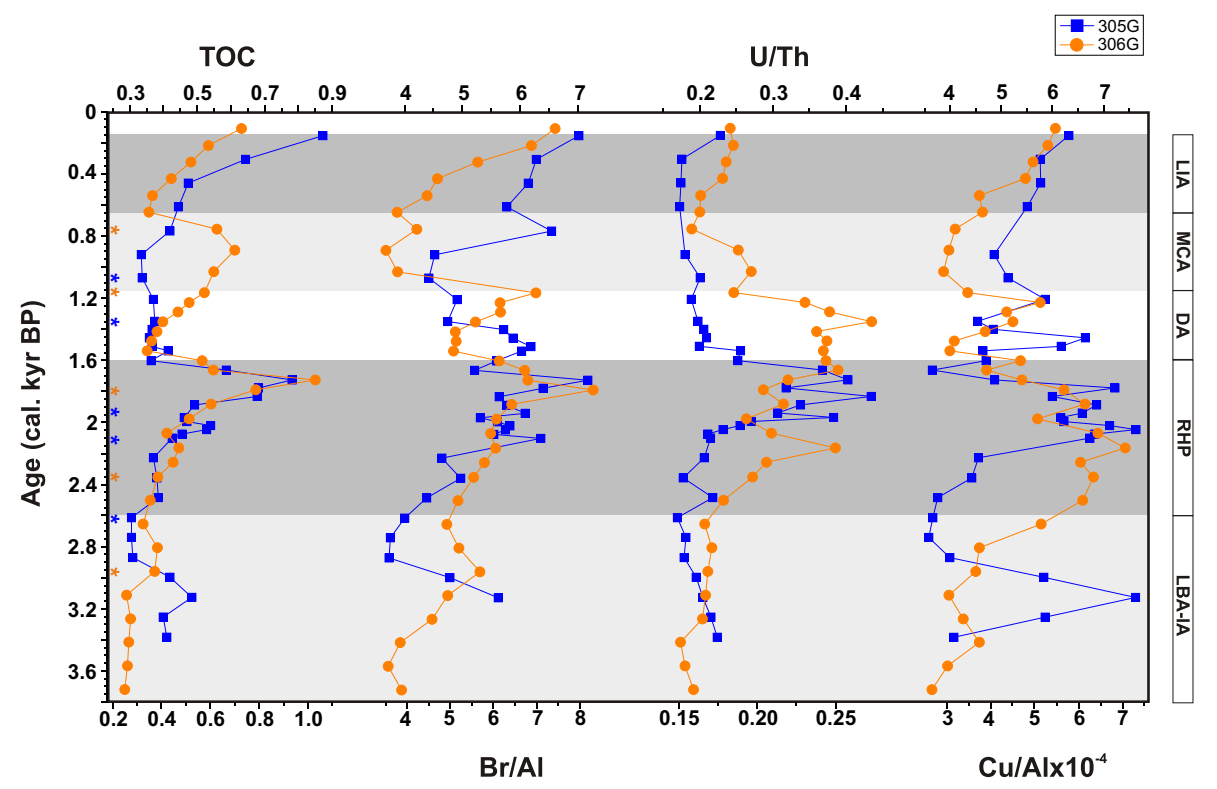

Fig. 6. Age-depth profile of paleo-productivity indicators $\left(\mathrm{Cu} / \mathrm{Al} \times 10^{-4}, \mathrm{TOC}, \mathrm{Br} / \mathrm{Al}\right.$ and $\mathrm{U} / \mathrm{Th}$ ) for cores $305 \mathrm{G}$ (blue squares) and $306 \mathrm{G}$ (orange circles). Light grey bars indicate dry periods (MCA: Medieval Climate Anomaly, DA: Dark Ages, LBA-IA: Late Bronze Age-Iron Age); dark grey bars indicate humid periods (LIA: Little Ice Age, RHP: Roman Humid Period). Asterisks indicate the AMS ${ }^{14} \mathrm{C}$ dates.

in contrast. Although $\mathrm{Cu} / \mathrm{Al}$ ratios display more erratic behaviour, it is possible to discern two $\mathrm{Cu} / \mathrm{Al}$ enrichments between 2000 and $1600 \mathrm{cal} \mathrm{yr} \mathrm{BP}$ and at the top of both cores as also drawn by $\mathrm{U} / \mathrm{Th}, \mathrm{Br} / \mathrm{Al}$ and TOC. Disagreements in these ratios for $1600-1150$ cal yr BP (U/Th in core $305 \mathrm{G}$ ) and $1150-650$ cal yr BP (TOC in core 306G) are explained in relation to post-depositional conditions.

Both Fe and Mn can precipitate as oxy-hydroxides when bottom waters are reventilated and penetrate downwards into the sediments, thus reflecting post-depositional oxidation fronts while organic matter burns down (e.g. deLange et al., 1989). The two sites display a constant post-depositional pattern of $\mathrm{Mn} / \mathrm{Al}$ except for sudden increases from 5 up to $9 \mathrm{~cm}$ depth at site $305 \mathrm{G}$, and from 5 to $9 \mathrm{~cm}$ and from 13 to $20 \mathrm{~cm}$ depth at site 306G (Fig. 9), evidencing post-depositional oxidation. $\mathrm{Fe} / \mathrm{Al}$ enrichments also occur immediately below $\mathrm{Mn}$ peaks, at $8 \mathrm{~cm}$ depth for site $305 \mathrm{G}$; yet a double peak is seen for site $306 \mathrm{G}$, at 12 and $19 \mathrm{~cm}$ depth. $\mathrm{Co} / \mathrm{Al}$ and $\mathrm{Mo} / \mathrm{Al}$ are also enriched in the post-depositional oxidation front at both sites, having most likely co-precipitated together with $\mathrm{Fe}$ and Mn oxy-hydroxides (e.g. Tribovillard et al., 2006) (Fig. 9). This front is moreover responsible for organic matter oxidation, as supported by the lower values and decreasing trend of TOC at coeval intervals (between 1350 and 600 cal yr BP in core $305 \mathrm{G}$ and from 1750 to $1350 \mathrm{cal} \mathrm{yrBP}$ and 900 450 cal yr BP in core 306G) (Fig. 6). Mn and Fe enrichments and early oxidation of organic matter above the redoxcline point to the typical boundary on oxic/suboxic pelagic sediments reported in Eastern Mediterranean sapropels and in uppermost hemipelagic sediments in the western Mediterranean (e.g. Thomson et al., 1999; Masqué et al., 2003).
The precipitation of $\mathrm{Mn}$ is found deeper in core $305 \mathrm{G}$ due to the coarser grain size distribution at this site, which allows for a farther downward progression of the oxidation front. Indeed, Masqué et al. (2003) reported post-depositional oxidation fronts ranging from $5.8 \mathrm{~cm}$ to as much as $15 \mathrm{~cm}$ depth in this sedimentary environment. In core $306 \mathrm{G}, \mathrm{Br}$ and TOC deposited between 1750 and 1350 cal yr BP were remobilized due to this post-depositional oxidation front (Figs. 6 and 9), and at 900-450 cal yr BP there is a preferential loss of Br-containing compounds in relation to TOC as noted by Price et al. (1970) during the early stages of diagenesis. In core $305 \mathrm{G}$, between 1350 and $600 \mathrm{cal} \mathrm{yr} \mathrm{BP}$, the post-depositional oxidation front reaching $9 \mathrm{~cm}$ depth may be responsible for remobilization of TOC, Br and U (Figs. 6 and 9). Elements such as uranium can be remobilized in sediments if oxygen penetrates up to the core depth where authigenic uranium has accumulated (e.g. McManus et al., 2005).

\section{Paleoclimatic and paleoceanographic conditions during the last $4000 \mathrm{yr}$}

\subsection{Late Bronze Age-Iron Age (LBA-IA) ( 23600-2600 cal yr BP).}

Dry conditions are dominant during this period, as indicated by the reduced riverine input from the catchment at both sites (a decreasing trend of fluvial derived-elements) and the relatively high values of the $\mathrm{Zr} / \mathrm{Al}$ ratio, associated with Saharan eolian input fluctuations (Fig. 5). This aridification trend coincides with a progressive evolution towards 


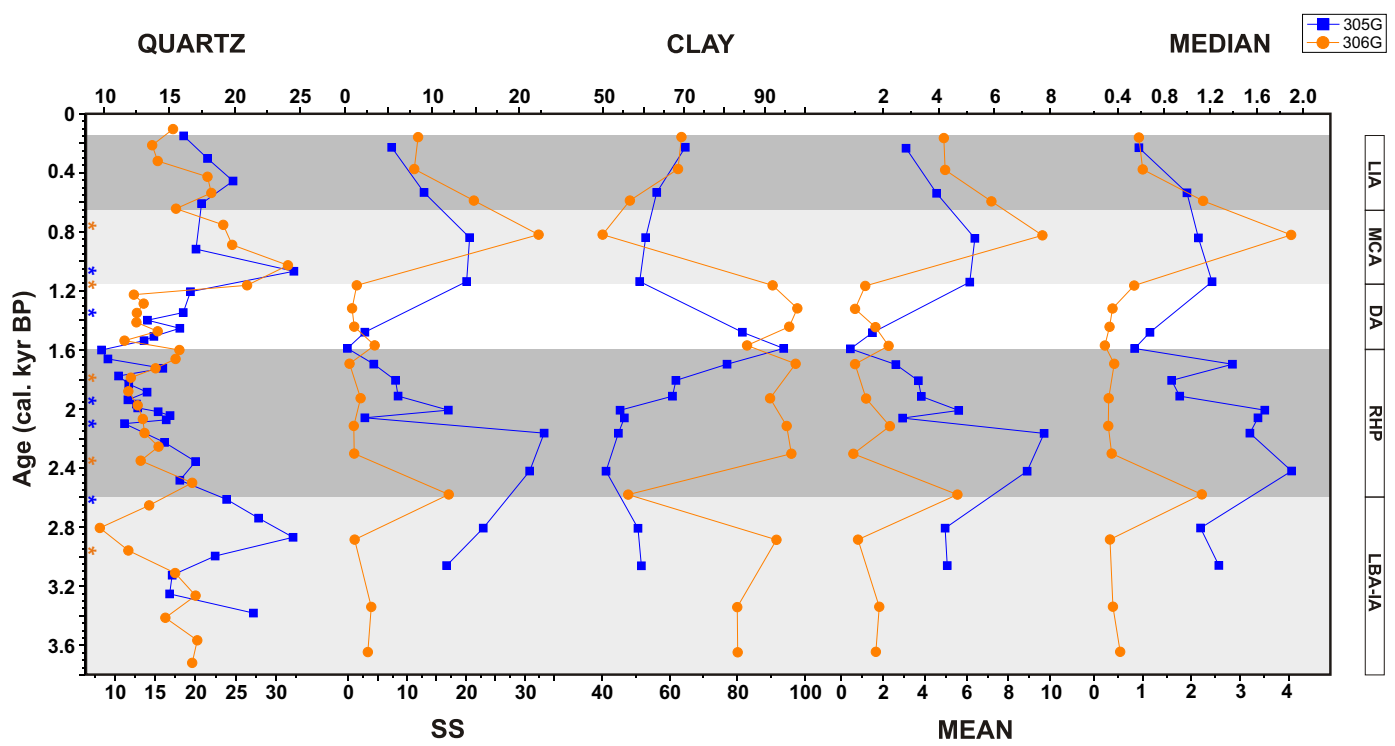

Fig. 7. Age-depth profile of grain size distribution: mean, median, SS (\%), clay (\%) and quartz content (\%) for cores $305 \mathrm{G}(\mathrm{blue}$ squares) and 306G (orange circles). Light grey bars indicate dry periods (MCA: Medieval Climate Anomaly, DA: Dark Ages, LBA-IA: Late Bronze Age-Iron Age); dark grey bars indicate humid periods (LIA: Little Ice Age, RHP: Roman Humid Period). Asterisks indicate the AMS ${ }^{14} \mathrm{C}$ dates.

typical Mediterranean climate and aridity, which gradually occurs from the middle Holocene (e.g. Wanner et al., 2008), and with one of the major periods of Holocene rapid climate change $(\mathrm{RCC})$ at the hemispheric scale $(\sim 3500$ 2500 cal yr BP) (Mayewski et al., 2004). During these RCC periods, a southward migration of the Inter-Tropical Convergence Zone (ITCZ) and thus higher intensity of dust export and wind speeds (Weldeab et al., 2003) have been described, which may explain the low latitude aridity associated with this period. Moreover, these arid conditions occurred in the context of a decline in the Northern Hemisphere solar insolation (Steinhilber et al., 2009), cooler air temperatures in Greenland from the middle LBA-IA (Greenland Ice Sheet Project $2 \delta^{18} \mathrm{O}$ record, GISP2 drill site) (Grootes and Stuiver, 1997) and detrital evidences of ice-rafting in the subpolar North Atlantic during the North Atlantic cold and arid event 2 ( 2800 cal yr BP) (Bond et al., 1997, 2001) (Fig. 10).

Furthermore, dry conditions have been widely described in the western Mediterranean region based on marine and terrestrial pollen records (Jalut et al., 2000, 2009; CombourieuNebout et al., 2009). Reduced river activity in Southern Europe (Magny et al., 2002; Macklin et al., 2006), cooling events with lower temperatures and faster flows in the Balearic Basin (Frigola et al., 2007), and a desiccation phase in a lacustrine record from Southern Spain (Carrión, 2002) are likewise reported for this time frame. Martín-Puertas et al. (2010) recorded a dry period supported by higher Saharan input into the Alboran Basin ( $\mathrm{Zr} / \mathrm{Al}$ ratio; core 300G) during this period.
The prevailing paleoceanographic conditions during this period entail faster flowing and better oxygenated bottom waters, evidenced at site $305 \mathrm{G}$ by the deposition of coarser grain size sediments, higher quartz content and lower redoxsensitive trace element values (Figs. 7 and 8). At site 306G, finer grain size, lower quartz content and high values of redox sensitive elements are found. The different locations of exposure would again explain the distinct sedimentary processes (Fig. 1a-c). Low TOC values as well as $\mathrm{Cu} / \mathrm{Al}, \mathrm{Br} / \mathrm{Al}$ and $\mathrm{U} / \mathrm{Th}$ ratios suggest low productivity and, owing to better oxygenated bottom sediments, lower organic matter preservation during this period (Fig. 6).

\subsection{The Roman Humid Period (RHP) ( 2600-1600 cal yr BP)}

The early and middle RHP ( $2600-1800$ cal yr BP) is still marked by dry conditions, signalled by the decrease of fluvial derived-elements (Fig. 5), although a decreasing trend in Saharan eolian input at both sites (Zr/Al, Fig. 5) suggests an ongoing establishment of more humid conditions in the western Mediterranean. Other records in this region support this scenario. Accordingly, dry conditions are described for palynological (Jalut et al., 2000, 2009; Combourieu-Nebout et al., 2009), marine (Frigola et al., 2007), lacustrine (Carrión, 2002), and fluvial records (Magny et al., 2002; Macklin et al., 2006) in the western Mediterranean.

The most noteworthy event coinciding with this time interval is the sudden rise in fluvial land-derived elements that occurred at the end of the RHP, around 1800 cal yr BP at both sites (Fig. 5), thus defining this period as the most humid by 


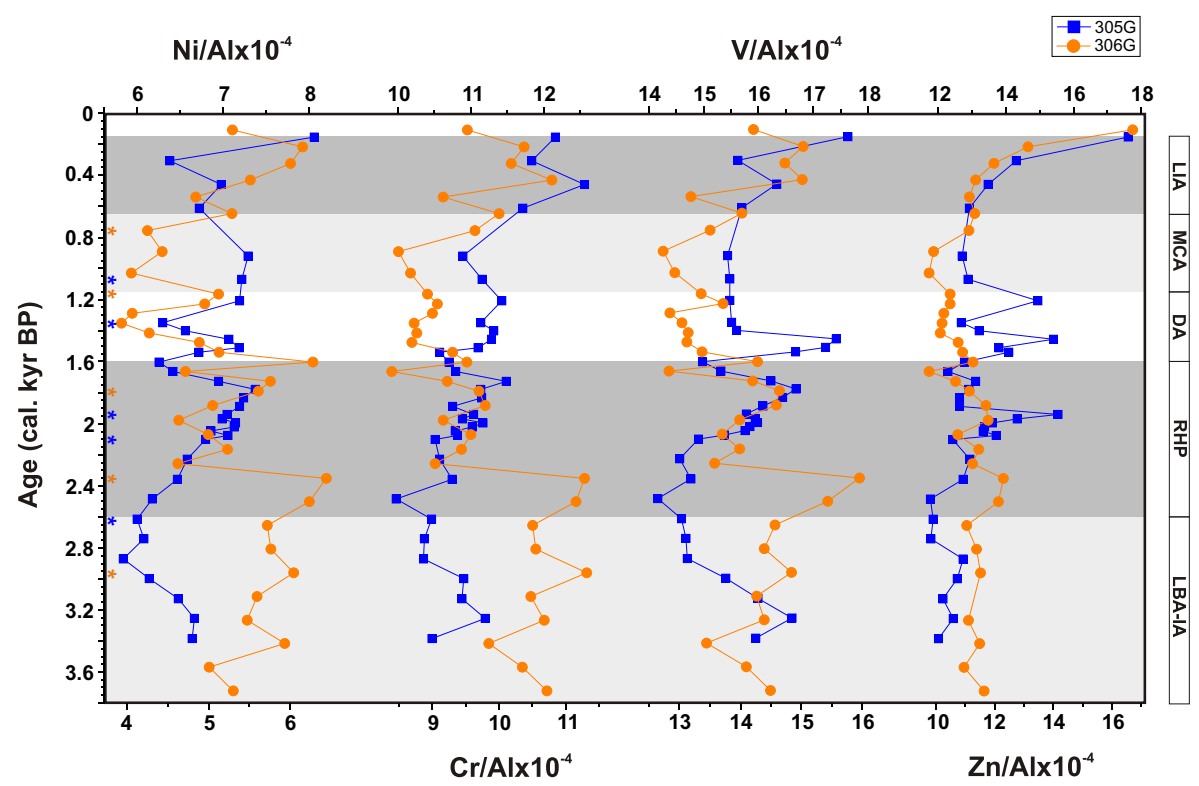

Fig. 8. Age-depth profile of redox proxies ( $\mathrm{V} / \mathrm{Al}, \mathrm{Cr} / \mathrm{Al}, \mathrm{Ni} / \mathrm{Al}$ and $\mathrm{Zn} / \mathrm{Al} \times 10^{-4}$ ratios) for cores $305 \mathrm{G}$ (blue squares) and $306 \mathrm{G}$ (orange circles). Light grey bars indicate dry periods (MCA: Medieval Climate Anomaly, DA: Dark Ages, LBA-IA: Late Bronze Age-Iron Age); dark grey bars indicate humid periods (LIA: Little Ice Age, RHP: Roman Humid Period). Asterisks indicate the AMS ${ }^{14} \mathrm{C}$ dates.

far of the last $4000 \mathrm{yr}$. The Saharan eolian input ( $\mathrm{Zr} / \mathrm{Al}$ ratio) remains low after $1800 \mathrm{cal}$ yr BP, achieving minimum values during this period and thus supporting the humid conditions (Fig. 5). This event coincides with higher solar insolation in the Northern Hemisphere (Steinhilber et al., 2009) and generally warm air temperatures in Greenland from the onset of the RHP to 2000 cal yr BP (Grootes and Stuiver, 1997) that sustain this humid period in the western Mediterrranean (Fig. 10).

Flooding events in the Iberian Peninsula are also recorded for this time (Macklin et al., 2006). Martín-Puertas et al. (2010) describe wetter conditions sharpening at 1700 cal yr BP in the Alboran Basin ( $\mathrm{Mg} / \mathrm{Al}$ ratio; ODP 976) and a decrease in the eolian input from the African margin ( $\mathrm{Zr} / \mathrm{Al}$ ratio; core $300 \mathrm{G})$ to characterize this period as the most humid of the Late Holocene in the southern part of the Iberian Peninsula.

The progressively finer grain size and lower quartz content for this interval (Fig. 7) indicate slower and less energetic flows, which are supported by slightly increased values of redox sensitive elements (Fig. 8) suggesting less oxygenated bottom conditions. Furthermore, the sudden increase in TOC values and organometallic ligands (Fig. 6) reveal increasing organic matter preservation due to these lower oxygen bottom water conditions. Thus, the most intense productivity and better preservation of the last $4000 \mathrm{yr}$ is exhibited during this period.

\subsection{The Dark Ages (DA) $(\sim 1600-1150$ cal yr BP)}

A progressive dryness peaking around $1300 \mathrm{cal} \mathrm{yr} \mathrm{BP}$ at both sites characterizes the DA, which coincides with decreasing solar insolation in the Northern Hemisphere (Steinhilber et al., 2009), another event of ice-rafting in the subpolar North Atlantic (North Atlantic cold event 1, $\sim 1400$ cal yr BP) (Bond et al., 1997, 2001), and cooler air temperatures in Greenland (Grootes and Stuiver, 1997). This fact is revealed by a decline in the riverine influence to the basin (Fig. 5) and a progressive increase in the Saharan eolian input suggested by the $\mathrm{Zr} / \mathrm{Al}$ ratio from $2000 \mathrm{cal} \mathrm{yr} \mathrm{BP}$ until the beginning of the MCA.

Faster bottom currents and more energetic hydrodynamic conditions are evoked by enhanced sortable silt and quartz content (Fig. 7), and by better oxygenated bottom waters as reflected by decreasing redox-sensitive elements (Fig. 8). Accordingly, lower TOC values as well as lesser $\mathrm{Cu} / \mathrm{Al}$, $\mathrm{Br} / \mathrm{Al}$ and U/Th ratios are indicative of poor organic matter preservation owing to well-oxygenated bottom sediments (Fig. 6). In addition, remobilization took place at core 305G due to a post-depositional oxidation front reaching $9 \mathrm{~cm}$ depth (Figs. 6 and 9) but not for U/Th at site 306G.

The dryness characterizing the DA is correlated with decreased humidity in the western Mediterranean, evidenced by forest cover regression episodes (Jalut et al., 2000, 2009; Combourieu-Nebout et al., 2009), a decrease in river activity in southern Europe (Magny et al., 2002; Macklin et al., 2006), cooling events in the Balearic Basin (Frigola et al., 2007), and lower lake levels in southern Spain (Carrión, 2002). 


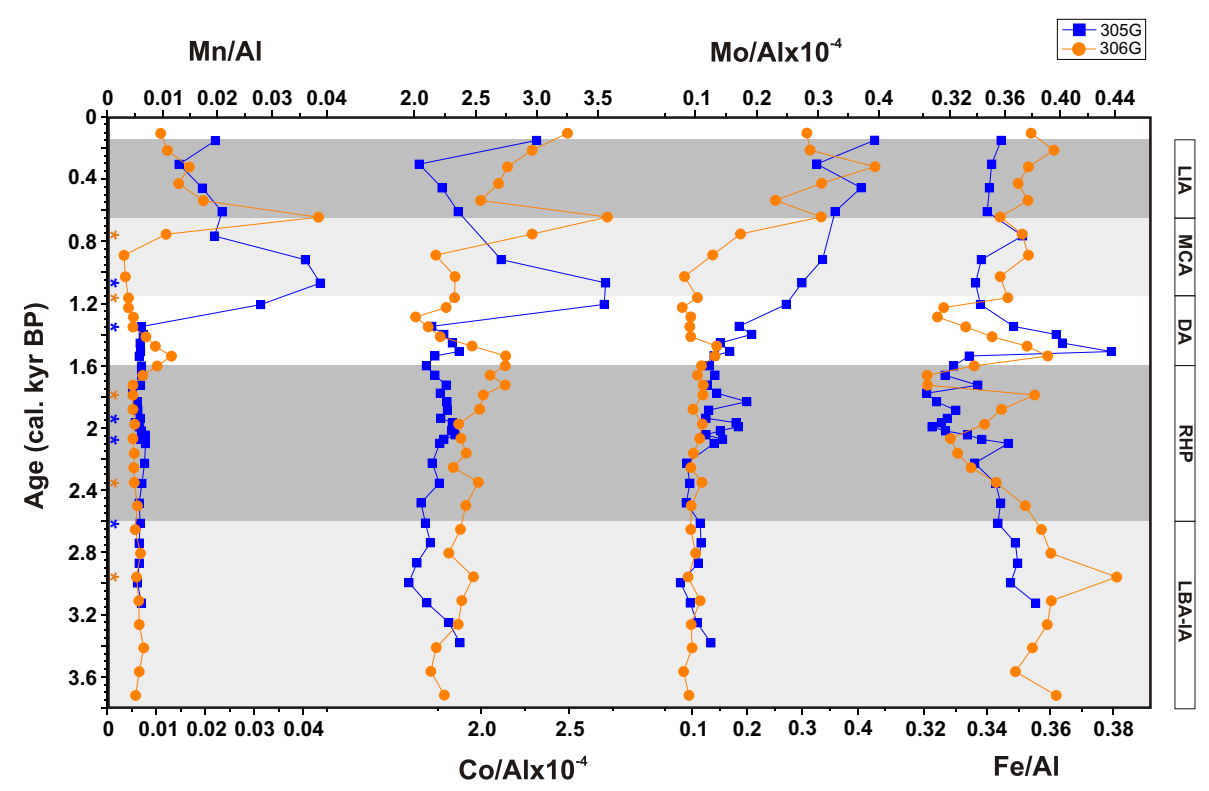

Fig. 9. Age-depth profile of post-depositional proxies $\left(\mathrm{Co} / \mathrm{Al}\right.$ and $\mathrm{Mo} / \mathrm{Al} \times 10^{-4}, \mathrm{Mn} / \mathrm{Al}$ and $\left.\mathrm{Fe} / \mathrm{Al}\right)$ for cores $305 \mathrm{G}$ (blue squares) and $306 \mathrm{G}$ (orange circles). Light grey bars indicate dry periods (MCA: Medieval Climate Anomaly, DA: Dark Ages, LBA-IA: Late Bronze Age-Iron Age); dark grey bars indicate humid periods (LIA: Little Ice Age, RHP: Roman Humid Period). Asterisks indicate the AMS ${ }^{14} \mathrm{C}$ dates.

\subsection{The Medieval Climate Anomaly (MCA) ( 1150-650 cal yr BP)}

Arid conditions are still predominant in the western Mediterranean during the MCA, as indicated by a decline in the fluvial input into the basin due to a decreasing trend of fluvialderived elements and higher $\mathrm{Zr} / \mathrm{Al}$ ratios, which indicate higher Saharan eolian input (Fig. 5). This arid phase is accentuated during the Medieval solar activity maximum $(\sim 850$ 700 cal yr BP) (Jirikowic and Damon, 1994) when values of fluvial-derived elements reach a minimum yet $\mathrm{Zr} / \mathrm{Al}$ ratios are still high. At the hemispheric scale, this time-interval coincides with one period of RCC $(\sim 1200-1000$ cal yr BP $)$ due to southward migration of the ITCZ (Mayewski et al., 2004), implying a greater intensity of dust export and wind speeds (Weldeab et al., 2003). Indeed, the highest Saharan eolian input during the last $4000 \mathrm{yr}$ occurred in this phase and in the LBA-IA, both coinciding with periods of RCC.

This phase can be inferred in the Mediterranean borderlands through changes in vegetation (Jalut et al., 2000, 2009; Combourieu-Nebout et al., 2009), and a decrease in river activity in southern Europe (Magny et al., 2002; Macklin et al., 2006). Drier conditions were also registered in marine, lacustrine and pollen records in the Iberian Peninsula during the MCA: lower water levels in lacustrine records, decreased fluvial supply and major Saharan dust particle input in the westernmost Mediterranean as evidenced by marine sediments, and higher xerophytic or heliophytic taxa vegetation documented by pollen records (Moreno et al., 2011; and references therein).
In terms of paleocenographic conditions, faster bottom currents and intense hydrodynamic conditions are suggested by an increase in grain size and quartz content (Fig. 7). Meanwhile, a decrease in redox-sensitive elements points to better oxygenated bottom waters (Fig. 8). Though in core $305 \mathrm{G}$, the post-depositional oxidation front reaching $9 \mathrm{~cm}$ remobilized TOC, $\mathrm{Br}$ and $\mathrm{U}$ (Figs. 6 and 9), the oxygenated bottom waters and stronger bottom currents suggest low preservation of organic matter.

Our record furthermore provides support of dominant positive NAO phases during the MCA over Europe (Trouet et al., 2009). Positive NAO phases in the Mediterranean region are linked to stronger westerlies transporting storms farther to the north and east and resulting in wetter winters over northern Europe - evidenced by stalagmites in North-Western Scotland (Proctor et al., 2000, 2002; Baker et al., 2011) and tree ring records from Germany (Büntgen et al., 2010) along with drier winters over southern Europe and northern Africa, reflected by precipitation data and tree ring records from North-Western Africa (Knippertz et al., 2003; Esper et al., 2007) (Fig. 10). Additionally, enhanced dust transport from the Saharan region to the North Atlantic Ocean and the Mediterranean Sea has been reported during positive NAO phases (Moulin et al., 1997). Certainly, the highest Saharan eolian input and the decreasing trend of fluvial-derived elements occurring during the MCA evidence drier conditions in the westernmost Mediterranean. Furthermore, paleocenographic conditions in this region dominated by oxygenated bottom waters and stronger bottom currents suggest enhanced formation of WMDW likely promoted by stronger westerlies during positive NAO phases. 


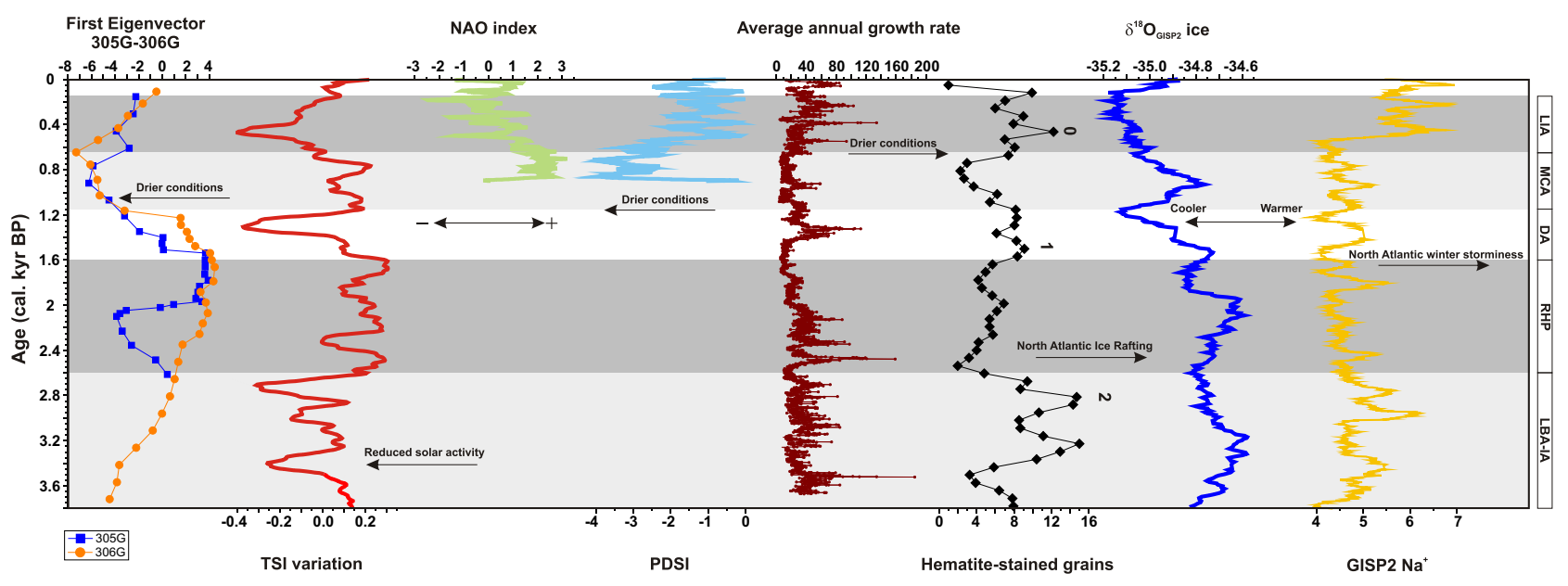

Fig. 10. First eigenvector of cores $305 \mathrm{G}$ (blue squares) and $306 \mathrm{G}$ (orange circles) compared with the TSI variations (W $\mathrm{m}^{-2}$ ) during the last $4000 \mathrm{yr}$ (30-point smoothed, red line) (Steinhilber et al., 2009), the NAO index during the last $1000 \mathrm{yr}$ (green line) (Trouet et al., 2009), the Palmer Drought Severity Index (PDSI) based on Cedrus Atlantica ring width from Morocco (North-Western Africa) reflecting aridity changes during the last $1000 \mathrm{yr}$ (10-point smoothed, light blue line) (Esper et al., 2007) and the growth rate variations of stalagmites (microns) from North-Western Scotland reflecting hydrological conditions during the last $4000 \mathrm{yr}$ (brown circles) (Proctor et al., 2000, 2002), the record of increased ice-drifting in the North Atlantic expressed as percentage variations of hematite-stained grains during the last $4000 \mathrm{yr}$ (black diamonds, numbers represent Bond cycles 0-2) (Bond et al., 2001), the high resolution $\delta^{18} \mathrm{O}$ record (\%o) (30-point smoothed, dark blue line) (Grootes and Stuiver, 1997) from the GISP2 ice core during the last $4000 \mathrm{yr}$ and the sea-salt Na concentration (ppb) (30-point smoothed, yellow line) (Mayewski et al., 1997). Light grey bars indicate dry periods (MCA: Medieval Climate Anomaly, DA: Dark Ages, LBA-IA: Late Bronze Age-Iron Age); dark grey bars indicate humid periods (LIA: Little Ice Age, RHP: Roman Humid Period).

\subsection{The Little Ice Age (LIA) $(\sim 650-150$ cal yr BP)}

The dry conditions recognized during the MCA are maintained during the first half of the LIA until $400 \mathrm{cal} \mathrm{yr} \mathrm{BP,} \mathrm{as}$ evidenced by a decreasing trend of fluvial-derived elements which reaches even lower values than during the MCA. The Saharan eolian input ratio ( $\mathrm{Zr} / \mathrm{Al}$ ratio) draws a declining trend throughout this period, attaining values as low as during the RHP (Fig. 5). At the hemispheric scale, this trend correlates with the latest period of significant RCC in the Northern Hemisphere ( $600-150$ cal yr BP) (Mayewski et al., 2004), as well the most recent evidence of ice-rafting in the subpolar North Atlantic (North Atlantic cold and arid event 0, $\sim 500$ cal yr BP) (Bond et al., 1997, 2001). Further records in the western Mediterranean mirror these conditions. Thus, Carrión (2002) recorded a desiccation phase in a lacustrine record from Southern Spain, Frigola et al. (2007) described cooling events in the Balearic Basin at this time, and Martín-Puertas et al. (2010) also recorded a decrease of riverine input during the first half of the LIA.

After 400 cal yr BP, a rise in fluvial land-derived elements (Fig. 5) defines the late LIA. Accordingly, enhanced fresh water input, meaning an establishment of wetter conditions in the western Mediterranean, can be envisaged during this time. A slight increase in the riverine input in the Alboran Sea Basin is also evidenced in westernmost Mediterranean records during the late LIA (Martín-Puertas et al., 2010); meanwhile higher lake levels and mexophytic vegetation which grows under moderately humid conditions occurred in the Iberian Peninsula (Moreno et al., 2011). Thus, increased fluvial input along with oceanographic oscillations may have also promoted enhanced productivity, as suggested by greater TOC values and organometallic ligands. Indeed, similar increase in productivity is also recognized during the LIA as far as the Sicily Channel, as evidenced by coccolithophore records by Incarbona et al. (2010).

These humid conditions correspond well with a change in the NAO index into a negative mode in the western Mediterranean. Weaker and southward displaced westerlies would bring enhanced precipitation and river discharges to the south of the Iberian Peninsula, as evidenced by our records after 400 cal yr BP. This displacement may have collapsed the formation of WMDW, as suggested by the less energetic and poorly oxygenated waters, seen in the increasing trend to finer grain size, lower quartz content (Fig. 7) and higher values of redox sensitive elements (Fig. 8). Furthermore, our records are compatible with a transition from predominant positive NAO phases to negative ones at 400 cal yr BP (Fig. 10).

\section{Forcing mechanisms driving natural climate variability during the Late Holocene}

Solar irradiance variations have been invoked as one of the main forcing mechanisms that drive natural climate 
variability on centennial to millennial time-scales during the Holocene at the hemispheric scale (e.g. van Geel et al., 1999; Crowley, 2000). At millennial scales, times of orbitallyinduced declines of solar irradiance in the Northern Hemisphere might have triggered ice-rafted debris discharges into the North Atlantic current (Bond et al., 2001). These abrupt events led to a southward advection of cooler and fresher surface water, thus reducing the North Atlantic Deep Water (NADW) production rate. The weakness of the global thermohaline circulation could allow these cold pole waters to spread into the Mediterranean Sea through the Strait of Gibraltar. Such events also correlate with an intensification of the atmospheric circulation over Greenland, producing stronger than normal northerly winds that could promote a strengthening of the WMDW production rate and thus of the Mediterranean thermohaline circulation (e.g. O'Brien et al., 1995; van Geel et al., 1999; Bond et al., 2001). These millennial-scale abrupt cooling events occur with a mean pacing of $1500 \mathrm{yr}$ during the Holocene, similar to the duration of the Dansgaard/Oeschger events that took place during the last deglacial period in the Alboran Sea Basin (e.g. Cacho et al., 1999).

Since detrital input is the main process managing deposition at sites 305G and 306G, we have selected the first eigenvector defined by PCA analyses at these sites to compare it with total solar irradiance (TSI) variations $\left(\mathrm{W} \mathrm{m}^{-2}\right)$ over the last $4000 \mathrm{yr}$ (Steinhilber et al., 2009) and the NAO index over the last $1000 \mathrm{yr}$ (Trouet et al., 2009) (Fig. 10). Thus, positive TSI values are achieved during the RHP and the MCA, whereas negative values are attained during the LBA-IA, the DA and the LIA. Three minimum negative values are reached during the whole record, two of them coinciding with the North Atlantic cold events described by Bond et al. (1997) (1400 and 2800 cal yr BP) and the other one taking place during the LIA (Fig. 10). These cold imprints in the TSI variations are mirrored at sites $305 \mathrm{G}$ and $306 \mathrm{G}$ by decreased fluvial input as discussed above (Fig. 5).

On the other hand, increasing trends of the first eigenvector in both cores are seen during the RHP (after 2000 cal yr BP) and the LIA, whereas decreasing ones are achieved during the LBA-IA, early and middle RHP, DA and the MCA (Fig. 10), respectively evidencing higher and lower riverine input into the basin. High TSI coincides with wet periods such as the RHP (higher riverine input), and low TSI agrees with dry periods, namely the LBA-IA and the DA (lower riverine input). Nevertheless, a lack of correlation throughout the MCA and the LIA in terms of total solar variations suggests some additional forcing affected detrital input in the western Mediterranean.

The MCA has been described as the most recent preindustrial warm period noted in Europe and over the Northern Hemisphere (Mann et al., 2008, 2009), also characterized by severe and prolonged droughts (Seager et al., 2007). Recently, Trouet et al. (2009) stated strongly-positive NAO phases for the MCA and negatives ones for the LIA as the responsible mechanism of this climate anomalies over the North Atlantic and elsewhere. Thus, the positive phase of the NAO leads to dry and cold winters in southern Europe, the Mediterranean, northern Africa, northern Canada and Greenland, and warm and wet winters in northern Europe and eastern North America (Wanner et al., 2001; Trigo et al., 2002). As explained above, climate and ocean conditions reconstructed from our records during the MCA and the LIA correspond with a positive and a negative phase of the NAO, thus inducing dry and humid conditions respectively in the western Mediterranean (Fig. 10). According to our records, wetter (drier) winters are also reflected by tree ring records from North-Western Africa during the LIA (MCA) (Esper et al., 2007). Meanwhile, drier (wetter) winters over northern Europe are evidenced by stalagmites in north-western Scotland during the LIA (MCA) (Proctor et al., 2000, 2002) (Fig. 10). Similarly, other records from different areas support our results. Thus, rising sea-salt $\mathrm{Na}^{+}$concentrations from the GISP2 ice core glaciochemical series (Mayewski et al., 1997) have been interpreted as a deepening of the Icelandic low atmospheric pressure, i.e. the deeper the low pressure the stronger the transport of sea-salt $\mathrm{Na}^{+}$by winds towards Greenland (Meeker and Mayewski, 2002). The weakening of the Icelandic low would lead more intense winter storminess and enhanced precipitation over the North Atlantic region as described for a negative state of the NAO during the LIA, being preceded by a period of negligible storm activity during the MCA (Fig. 10). These concentrations coincide with the synchronicity of colder temperatures during the LIA and warmer during the MCA, as recorded by the $\delta^{18} \mathrm{O}$ ice GISP2 ice core in Greenland (Grootes and Stuiver, 1997) which is consistent with detrital evidences of an increased ice-drifting event in the North Atlantic during the LIA (Bond et al., 2001) (Fig. 10).

Hence, our records further support the NAO as a regional mechanism driving natural climate variability together with the TSI in the western Mediterranean during the Late Holocene. In this way, Seager et al. (2007) attributed the dry conditions during the MCA in the Mediterranean region to a prevailed positive mode of the NAO and Shindell et al. (2001) pointed out a coupled between low solar insolation and a negative mode of the NAO as responsible of the low temperatures in Europe during the Maunder Minimum at the late LIA. These results also sustain the link of the Mediterranean climate with the North Atlantic climate system driven by atmospheric forcing related to the NAO at centennial and millennial scales during the last $4000 \mathrm{yr}$. 


\section{Conclusions}

Fluctuations in chemical and mineralogical composition as well as grain size distribution in two deep-sea marine records from the western Mediterranean Sea reveal climate oscillations over the past $4000 \mathrm{yr}$. These records provide further insight into the response of this highly sensitive area to internal climate variability, allowing for the identification and characterization of humid (LIA and RHP) and dry (MCA, DA and LBA-IA) periods. An increase in riverine input (fluvialderived detrital elements $-\mathrm{Rb} / \mathrm{Al}, \mathrm{Ba} / \mathrm{Al}, \mathrm{REE} / \mathrm{Al}, \mathrm{Si} / \mathrm{Al}$, $\mathrm{Ti} / \mathrm{Al}, \mathrm{Mg} / \mathrm{Al}$ and $\mathrm{K} / \mathrm{Al}$ ratios) and a decrease in Saharan eolian input ( $\mathrm{Zr} / \mathrm{Al}$ ratio) characterize the RHP and the LIA. Additionally, weaker bottom currents (lower SS), oxygenpoor bottom waters (high $\mathrm{V} / \mathrm{Al}, \mathrm{Cr} / \mathrm{Al}, \mathrm{Ni} / \mathrm{Al}$ and $\mathrm{Zn} / \mathrm{Al}$ ratios), and well-preserved marine organic matter (TOC content and $\mathrm{Br} / \mathrm{Al}$ ratio, $\mathrm{U}$ and $\mathrm{Cu}$ as organometallic ligands) are evidenced, whereas essentially opposite paleoenvironmental and paleoceanographic conditions are recognized during the LBA-IA, the DA and the MCA. Likewise, the highest TOC values achieved during the late RHP, together with increasing preservation of organic matter, point to this time period as exhibiting by far the most intense productivity of the last $4000 \mathrm{yr}$. Comparison of the first eigenvector defined by PCA at site $305 \mathrm{G}$ and $306 \mathrm{G}$, which represents the detrital input into the basin, with natural external forcing mechanisms of climate variability (such as the TSI and the NAO), would underline the TSI as one of the main mechanisms behind natural climate variability on millennial scales. Further influential sources are the modulation of the NAO, a regional prevailing pattern of winter climate variability in the North Atlantic region, and driving natural climate variability on decadal to centennial scales during the MCA and the LIA in the western Mediterranean.

Acknowledgements. This work was financed by Projects CGL2009-07603, CTM2009-07715 (Secretaría de Estado de Investigación, MICCIN, EU FEDER), 200800050084447 (MARM), Project RNM 05212 and Research Group 0179 (Junta de Andalucía) and the Training-Through-Research Programme. We are grateful to CSD2006-00041 (TOPOIBERIA) and CSD2007-00067 (GRACCIE) projects, and Centre for Scientific Instrumentation (CIC-UGR), National Centre for Accelerators (Seville, Spain), Poznan Radiocarbon Laboratory (Poland), Andalusian Institute of Earth Sciences (CSIC-UGR) and Department of Mineralogy and Petrology for the analyses. We are likewise grateful to Alpiste for providing the maps, and to R. Corral, D. Ortega, E. Holanda, C. Niembro, L. González, E. Abarca and J. Santamarina, as well as the CIC personnel for their laboratory assistance. Constructive comments and suggestions by three anonymous reviewers greatly improved the final manuscript. J. L. Sanders post-edited the English style.

Edited by: P. Ziveri

\section{References}

Baker, A., Wilson, R., Fairchild, I. J., Franke, J., Spötl, C., Mattey, D., Trouet, V., and Fuller, L.: High resolution $\delta^{18} \mathrm{O}$ and $\delta^{13} \mathrm{C}$ records from an annually laminated Scottish stalagmite and relationship with last millennium climate, Global Planet. Change, 79, 303-311, doi:10.1016/j.gloplacha.2010.12.007, 2011.

Bárcena, M. A., Cacho, I., Abrantes, F., Sierro, F. J., Grimalt, J. O., and Flores, J. A.: Paleoproductivity variations related to climatic conditions in the Alboran Sea (western Mediterranean) during the last glacial-interglacial transition: the diatom record, Palaeogeogr. Palaeoclimatol. Palaeoecol., 167, 337-357, doi:10.1016/S0031-0182(00)00246-7, 2001.

Bárcena, M. A., Isla, E., Plaza, A., Flores, J. A., Sierro, F. J., Masqué, P., Sánchez-Cabeza, J. A., and Palanques, A.: Bioaccumulation record and paleoclimatic significance in the Western Bransfield Strait, The last 2000 years, Deep-Sea Res. Pt. II, 49, 935-950, doi:10.1016/S0967-0645(01)00132-1, 2002.

Bea, F.: Residence of REE, Y, Th and U in granites and crustal protoliths; implications for the chemistry of crustal melts, J. Petrol., 37, 521-552, doi:10.1093/petrology/37.3.521, 1996.

Berglund, B. E.: Human impact and climate changes - synchronous events and a causal link?, Quatern. Int., 105, 7-12, doi:10.1016/S1040-6182(02)00144-1, 2003.

Bethoux, J. P.: Budgets of the Mediterranean Sea: their dependance on the local climate and on the characteristics of the Atlantic waters, Oceanol. Acta, 2, 157-163, 1979.

Bianchi, G. G. and McCave, I. N.: Holocene periodicity in North Atlantic climate and deep-ocean flow south of Iceland, Nature, 397, 515-517, doi:10.1038/17362, 1999.

Blackford, J. J. and Chambers, F. M.: Proxy climate record for the last 1000 years from Irish blanket peat and a possible link to solar variability, Earth Planet. Sc. Lett., 133, 145-150, doi:10.1016/0012-821X(95)00072-K, 1995.

Bolle, H. J.: Climate, climate variability and impacts in the Mediterranean area: an overview, in: Mediterranean Climate: variability and trends, edited by: Bolle, H. J., Springer, New York, 5-86, 2003.

Bond, G., Showers, W., Cheseby, M., Lotti, R., Almasi, P., deMenocal, P., Priore, P., Cullen, H., Hajdas, I., and Bonani, G.: A pervasive millennial-scale cycle in North Atlantic Holocene and Glacial climates, Science, 278, 1257-1266, doi:10.1126/science.278.5341.1257, 1997.

Bond, G., Kromer, B., Beer, J., Muscheler, R., Evans, M. N., Showers, W., Hoffmann, S., Lotti-Bond, R., Hajdas, I., and Bonani, G.: Persistent solar influence on North Atlantic climate during the Holocene, Science, 294, 2130-2136, doi:10.1126/science.1065680, 2001.

Bout-Roumazeilles, V., Combourieu-Nebout, N., Peyron, O., Cortijo, E., Landais, A., and Masson-Delmotte, V.: Connection between South Mediterranean climate and North African atmospheric circulation during the last $50,000 \mathrm{yr}$ BP North Atlantic cold events, Quaternary Sci. Rev., 26, 3197-3215, doi:10.1016/j.quascirev.2007.07.015, 2007.

Bradley, R. S. and Jones, P. D.: "Little Ice Age" summer temperature variations: their nature and relevance to recent global warming trends, Holocene, 3, 367-376, doi:10.1177/095968369300300409, 1993.

Broecker, W. S.: Was the Medieval Warm Period global?, Science, 291, 1497-1499, doi:10.1126/science.291.5508.1497, 2001. 
Büntgen, U., Trouet, V., Frank, D., Leuschner, H. H., Friedrichs, D., Luterbacher, J., and Esper, J.: Tree-ring indicators of German summer drought over the last millennium, Quaternary Sci. Rev., 29, 1005-1016, doi:10.1016/j.quascirev.2010.01.003, 2010.

Cacho, I., Grimalt, J. O., Pelejero, C., Canals, M., Sierro, F. J., Flores, J. A., and Shackleton, N.: Dansgaard-Oeschger and Heinrich event imprints in Alboran Sea paleotemperatures, Paleoceanography, 14, 698-705, doi:10.1029/1999PA900044, 1999.

Cacho, I., Grimalt, J. O., Canals, M., Sbaffi, L., Shackleton, N. J., Schönfeld, J., and Zahn, R.: Variability of the western Mediterranean Sea surface temperature during the last 25,000 years and its connection with the Northern Hemisphere climatic changes, Paleoceanography, 16, 40-52, doi:10.1029/2000pa000502, 2001.

Calvert, S. E. and Fontugne, M. R.: On the late PleistoceneHolocene sapropel record of climatic and oceanographic variability in the eastern Mediterranean, Paleoceanography, 16, 7894, doi:10.1029/1999pa000488, 2001.

Carrión, J. S.: Patterns and processes of Late Quaternary environmental change in a montane region of southwestern Europe, Quaternary Sci. Rev., 21, 2047-2066, 2002.

Casford, J. S. L., Abu-Zied, R., Rohling, E. J., Cooke, S., Boessenkool, K. P., Brinkhuis, H., De Vries, C., Wefer, G., Geraga, M., Papatheodorou, G., Croudace, I., Thomson, J., and Lykousis, V.: Mediterranean climate variability during the Holocene, Mediterr. Mar. Sci., 2, 45-55, 2001.

Chamley, H.: Clay Sedimentology, Springer-Verlag, Berlin, 1989.

Comas, M. C. and Ivanov, M. K.: Eastern Alboran margin: the transition between the Alboran and the Balearic-Algerian basins, in: Interdisciplinary geoscience studies of the Gulf of Cadiz and Western Mediterranean basins, edited by: Kenyon, N. H., Ivanov, M. K., Akhmetzhanov, A. M., and Kozlova, E. V., IOC Technical Series No. 70, UNESCO, 48-61, 2006.

Combourieu-Nebout, N., Turon, J. L., Zahn, R., Capotondi, L., Londeix, L., and Pahnke, K.: Enhanced aridity and atmospheric high-pressure stability over the western Mediterranean during the North Atlantic cold events of the past 50 k.y., Geology, 30, 863866, doi:10.1130/0091-7613(2002)030<0863:eaaahp >2.0.co;2, 2002.

Combourieu-Nebout, N., Peyron, O., Dormoy, I., Desprat, S., Beaudouin, C., Kotthoff, U., and Marret, F.: Rapid climatic variability in the west Mediterranean during the last 25,000 years from high resolution pollen data, Clim. Past, 5, 503-521, doi:10.5194/cp5-503-2009, 2009.

Crowley, T. J.: Causes of climate change over the past 1000 years, Science, 289, 270-277, doi:10.1126/science.289.5477.270, 2000.

Crowley, T. J. and Lowery, T. S.: How warm was the Medieval Warm Period?, AMBIO, 29, 51-54, doi:10.1579/0044-744729.1.51, 2000.

Dansgaard, W., Johnsen, S. J., Clausen, H. B., Dahl-Jensen, D., Gundestrup, N. S., Hammer, C. U., Hvidberg, C. S., Steffensen, J. P., Sveinbjornsdottir, A. E., Jouzel, J., and Bond, G.: Evidence for general instability of past climate from a $250-\mathrm{kyr}$ ice-core record, Nature, 364, 218-220, doi:10.1038/364218a0, 1993.

Dawson, A. G., Hickey, K., Mayewski, P. A., and Nesje, A.: Greenland (GISP2) ice core and historical indicators of complex North Atlantic climate changes during the fourteenth century, Holocene, 17, 427-434, doi:10.1177/0959683607077010,
2007.

deLange, G. J., Middelburg, J. J., and Pruysers, P. A.: Middle and Late Quaternary depositional sequences and cycles in the eastern Mediterranean, Sedimentology, 36, 151-156, doi:10.1111/j.1365-3091.1989.tb00827.x, 1989.

deMenocal, P., Ortiz, J., Guilderson, T., Adkins, J., Sarnthein, M., Baker, L., and Yarusinsky, M.: Abrupt onset and termination of the African Humid Period: rapid climate responses to gradual insolation forcing, Quaternary Sci. Rev., 19, 347-361, doi:10.1016/S0277-3791(99)00081-5, 2000.

Development Core Team, R.: R: A language and environment for statistical computing, available at: http://www.R-project.org, (last access: April 2011), R package version 2.13.0, 2011.

Eagle, M., Paytan, A., Arrigo, K. R., van Dijken, G., and Murray, R. W.: A comparison between excess barium and barite as indicators of carbon export, Paleoceanography, 18, 1021, doi:10.1029/2002pa000793, 2003.

Esper, J., Cook, E. R., and Schweingruber, F. H.: Lowfrequency signals in long tree-ring chronologies for reconstructing past temperature variability, Science, 295, 2250-2253, doi:10.1126/science.1066208, 2002.

Esper, J., Frank, D., Büntgen, U., Verstege, A., Luterbacher, J., and Xoplaki, E.: Long-term drought severity variations in Morocco, Geophys. Res. Lett., 34, L17702, doi:10.1029/2007gl030844, 2007.

Fabres, J., Calafat, A., Sánchez-Vidal, A., Canals, M., and Heussner, S.: Composition and spatio-temporal variability of particle fluxes in the Western Alboran Gyre, Mediterranean Sea, J. Mar. Syst., 33-34, 431-456, doi:10.1016/S0924-7963(02)00070-2, 2002.

Fagel, N.: Marine clay minerals, deep circulation and climate, in: Paleoceanography of the Late Cenozoic, edited by: HillaireMarcel, C. and Vernal, A. D., Elsevier, Amsterdam, 139-184, 2007.

Frigola, J., Moreno, A., Cacho, I., Canals, M., Sierro, F. J., Flores, J. A., Grimalt, J. O., Hodell, D. A., and Curtis, J. H.: Holocene climate variability in the western Mediterranean region from a deepwater sediment record, Paleoceanography, 22, PA2209, doi:10.1029/2006pa001307, 2007.

Frigola, J., Moreno, A., Cacho, I., Canals, M., Sierro, F. J., Flores, J. A., and Grimalt, J. O.: Evidence of abrupt changes in Western Mediterranean Deep Water circulation during the last 50 kyr: A high-resolution marine record from the Balearic Sea, Quatern. Int., 181, 88-104, doi:10.1016/j.quaint.2007.06.016, 2008.

García-Orellana, J., Pates, J. M., Masqué, P., Bruach, J. M., and Sánchez-Cabeza, J. A.: Distribution of artificial radionuclides in deep sediments of the Mediterranean Sea, Sci. Total Environ., 407, 887-898, doi:10.1016/j.scitotenv.2008.09.018, 2009.

Grootes, P. M. and Stuiver, M.: Oxygen 18/16 variability in Greenland snow and ice with $10^{-3}$ to $10^{-5}$-year time resolution, J. Geophys. Res., 102, 26455-26470, doi:10.1029/97jc00880, 1997.

Guerzoni, S., Molinaroli, E., and Chester, R.: Saharan dust inputs to the western Mediterranean Sea: depositional patterns, geochemistry and sedimentological implications, Deep-Sea Res. Pt. II, 44, 631-654, doi:10.1016/S0967-0645(96)00096-3, 1997.

Hall, I. R. and McCave, I. N.: Palaeocurrent reconstruction, sediment and thorium focussing on the Iberian margin over the last $140 \mathrm{ka}$, Earth Planet. Sc. Lett., 178, 151-164, 
doi:10.1016/S0012-821X(00)00068-6, 2000.

Horstman, E. L.: The distribution of lithium, rubidium and caesium in igneous and sedimentary rocks, Geochim. Cosmochim. Acta, 12, 1-28, doi:10.1016/0016-7037(57)90014-5, 1957.

Hughes, M. K. and Diaz, H. F.: Was there a "Medieval Warm Period", and if so, where and when?, Clim. Change, 26, 109-142, doi:10.1007/BF01092410, 1994.

Hurrell, J. W.: Decadal trends in the North Atlantic Oscillation: Regional temperatures and precipitation, Science, 269, 676-679, doi:10.1126/science.269.5224.676, 1995.

Incarbona, A., Ziveri, P., Di Stefano, E., Lirer, F., Mortyn, G., Patti, B., Pelosi, N., Sprovieri, M., Tranchida, G., Vallefuoco, M., Albertazzi, S., Bellucci, L. G., Bonanno, A., Bonomo, S., Censi, P., Ferraro, L., Giuliani, S., Mazzola, S., and Sprovieri, R.: The impact of the Little Ice Age on coccolithophores in the central Mediterranean Sea, Clim. Past, 6, 795-805, doi:10.5194/cp-6795-2010, 2010.

Issar, A.: Climate changes during The Holocene and their impact on hydrological systems, Cambridge University Press, Cambridge, UK, 2003.

Jalut, G., Esteban Amat, A., Bonnet, L., Gauquelin, T., and Fontugne, M.: Holocene climatic changes in the Western Mediterranean, from south-east France to south-east Spain, Palaeogeogr. Palaeoclimatol. Palaeoecol., 160, 255-290, doi:10.1016/S0031-0182(00)00075-4, 2000.

Jalut, G., Dedoubat, J. J., Fontugne, M., and Otto, T.: Holocene circum-Mediterranean vegetation changes: Climate forcing and human impact, Quatern. Int., 200, 4-18, doi:10.1016/j.quaint.2008.03.012, 2009.

Jiménez-Espejo, F. J., Martínez-Ruiz, F., Sakamoto, T., Iijima, K., Gallego-Torres, D., and Harada, N.: Paleoenvironmental changes in the western Mediterranean since the last glacial maximum: High resolution multiproxy record from the Algero-Balearic basin, Palaeogeogr. Palaeoclimatol. Palaeoecol., 246, 292-306, doi:10.1016/j.palaeo.2006.10.005, 2007.

Jiménez-Espejo, F. J., Martínez-Ruiz, F., Rogerson, M., GonzálezDonoso, J. M., Romero, O. E., Linares, D., Sakamoto, T., Gallego-Torres, D., Rueda Ruiz, J. L., Ortega-Huertas, M., and Pérez Claros, J. A.: Detrital input, productivity fluctuations, and water mass circulation in the westernmost Mediterranean Sea since the Last Glacial Maximum, Geochem. Geophy. Geosy., 9, Q11U02, doi:10.1029/2008gc002096, 2008.

Jirikowic, J. L. and Damon, P. E.: The medieval solar activity maximum, Clim. Change, 26, 309-316, doi:10.1007/BF01092421, 1994.

Jones, M. D., Roberts, C. N., Leng, M. J., and Türkes, M.: A highresolution late Holocene lake isotope record from Turkey and links to North Atlantic and monsoon climate, Geology, 34, 361364, doi:10.1130/g22407.1, 2006.

Jones, P. D., Osborn, T. J., and Briffa, K. R.: The evolution of climate over the Last Millennium, Science, 292, 662-667, doi:10.1126/science.1059126, 2001.

Kisch, H. J.: Illite crystallinity: recommendations on sample preparation, X-ray diffraction settings, and interlaboratory samples, J. Metamorph. Geo., 9, 665-670, doi:10.1111/j.15251314.1991.tb00556.x, 1991.

Knippertz, P., Christoph, M., and Speth, P.: Long-term precipitation variability in Morocco and the link to the large-scale circulation in recent and future climates, Meteorol. Atmos. Phys, 83, 67-88, doi:10.1007/s00703-002-0561-y, 2003.

Kolla, V., Biscaye, P. E., and Hanley, A. F.: Distribution of quartz in late Quaternary Atlantic sediments in relation to climate, Quatern. Res., 11, 261-277, doi:10.1016/0033-5894(79)900085, 1979.

Lamb, H. H.: The early medieval warm epoch and its sequel, Palaeogeogr. Palaeoclimatol. Palaeoecol., 1, 13-37, doi:10.1016/0031-0182(65)90004-0, 1965.

Lionello, P., Malanotte-Rizzoli, P., Boscolo, R., Alpert, P., Artale, V., Li, L., Luterbacher, J., May, W., Trigo, R., Tsimplis, M., Ulbrich, U., and Xoplaki, E.: The Mediterranean climate: An overview of the main characteristics and issues, in: Mediterranean climate variability, edited by: Lionello, P., MalanotteRizzoli, P., and Boscolo, R., Elsevier, Amsterdam, 1-26, 2006.

Macklin, M. G., Benito, G., Gregory, K. J., Johnstone, E., Lewin, J., Michczynska, D. J., Soja, R., Starkel, L., and Thorndycraft, V. R.: Past hydrological events reflected in the Holocene fluvial record of Europe, Catena, 66, 145-154, doi:10.1016/j.catena.2005.07.015, 2006.

Magny, M.: Holocene climate variability as reflected by midEuropean lake-level fluctuations and its probable impact on prehistoric human settlements, Quatern. Int., 113, 65-79, doi:10.1016/S1040-6182(03)00080-6, 2004.

Magny, M., Guiot, J., and Schoellammer, P.: Quantitative reconstruction of Younger Dryas to Mid-Holocene paleoclimates at Le Locle, Swiss Jura, using pollen and lake-level data, Quatern. Res., 56, 170-180, doi:10.1006/qres.2001.2257, 2001.

Magny, M., Miramont, C., and Sivan, O.: Assessment of the impact of climate and anthropogenic factors on Holocene Mediterranean vegetation in Europe on the basis of palaeohydrological records, Palaeogeogr. Palaeoclimatol. Palaeoecol., 186, 47-59, doi:10.1016/S0031-0182(02)00442-X, 2002.

Mangini, A., Blumbach, P., Verdes, P., Spötl, C., Scholz, D., Machel, H., and Mahon, S.: Combined records from a stalagmite from Barbados and from lake sediments in Haiti reveal variable seasonality in the Caribbean between 6.7 and $3 \mathrm{ka} \mathrm{BP}$, Quaternary Sci. Rev., 26, 1332-1343, doi:10.1016/j.quascirev.2007.01.011, 2007.

Mann, M. E., Zhang, Z., Hughes, M. K., Bradley, R. S., Miller, S. K., Rutherford, S., and Ni, F.: Proxy-based reconstructions of hemispheric and global surface temperature variations over the past two millennia, P. Natl. Acad. Sci., 105, 13252-13257, doi:10.1073/pnas.0805721105, 2008.

Mann, M. E., Zhang, Z., Rutherford, S., Bradley, R. S., Hughes, M. K., Shindell, D., Ammann, C., Faluvegi, G., and Ni, F.: Global signatures and dynamical origins of the Little Ice Age and Medieval Climate Anomaly, Science, 326, 1256-1260, doi:10.1126/science.1177303, 2009.

Martin, J. D.: Using XPowder: A software package for Powder XRay diffraction analysis, Spain, 105 pp., 2004.

Martín-Puertas, C., Jiménez-Espejo, F., Martínez-Ruiz, F., NietoMoreno, V., Rodrigo, M., Mata, M. P., and Valero-Garcés, B. L.: Late Holocene climate variability in the southwestern Mediterranean region: an integrated marine and terrestrial geochemical approach, Clim. Past, 6, 807-816, doi:10.5194/cp-6-807-2010, 2010.

Martínez-Ruiz, F., Paytan, A., Kastner, M., González-Donoso, J. M., Linares, D., Bernasconi, S. M., and Jiménez-Espejo, F. J.: A comparative study of the geochemical and mineralogical 
characteristics of the S1 sapropel in the western and eastern Mediterranean, Palaeogeogr. Palaeoclimatol. Palaeoecol., 190, 23-37, doi:10.1016/S0031-0182(02)00597-7, 2003.

Masqué, P., Fabres, J., Canals, M., Sánchez-Cabeza, J. A., SánchezVidal, A., Cacho, I., Calafat, A. M., and Bruach, J. M.: Accumulation rates of major constituents of hemipelagic sediments in the deep Alboran Sea: a centennial perspective of sedimentary dynamics, Mar. Geol., 193, 207-233, doi:10.1016/S00253227(02)00593-5, 2003.

Masson, V., Vimeux, F., Jouzel, J., Morgan, V., Delmotte, M., Ciais, P., Hammer, C., Johnsen, S., Lipenkov, V. Y., MosleyThompson, E., Petit, J.-R., Steig, E. J., Stievenard, M., and Vaikmae, R.: Holocene climate variability in Antarctica based on 11 ice-core isotopic records, Quatern. Res., 54, 348-358, doi:10.1006/qres.2000.2172, 2000.

Mayewski, P. A., Meeker, L. D., Twickler, M. S., Whitlow, S., Yang, Q., Lyons, W. B., and Prentice, M.: Major features and forcing of high-latitude northern hemisphere atmospheric circulation using a 110,000-year-long glaciochemical series, J. Geophys. Res., 102, 26345-26366, doi:10.1029/96jc03365, 1997.

Mayewski, P. A., Rohling, E. E., Curt Stager, J., Karlén, W., Maasch, K. A., David Meeker, L., Meyerson, E. A., Gasse, F., van Kreveld, S., Holmgren, K., Lee-Thorp, J., Rosqvist, G., Rack, F., Staubwasser, M., Schneider, R. R., and Steig, E. J.: Holocene climate variability, Quatern. Res., 62, 243-255, doi:10.1016/j.yqres.2004.07.001, 2004.

McCave, I. N. and Hall, I. R.: Size sorting in marine muds: Processes, pitfalls, and prospects for paleoflowspeed proxies, Geochem. Geophy. Geosy., 7, Q10N05, doi:10.1029/2006gc001284, 2006.

McCave, I. N., Manighetti, B., and Robinson, S. G.: Sortable silt and fine sediment size/composition slicing: parameters for palaeocurrent speed and palaeoceanography, Paleoceanography, 10, 593-610, doi:10.1029/94pa03039, 1995.

McDermott, F., Mattey, D. P., and Hawkesworth, C.: Centennialscale Holocene climate variability revealed by a high-resolution speleothem $\delta^{18} \mathrm{O}$ record from SW Ireland, Science, 294, 13281331, doi:10.1126/science.1063678, 2001.

McDonough, W. F. and Sun, S. S.: The composition of the Earth, Chem. Geol., 120, 223-253, doi:10.1016/0009-2541(94)001404, 1995.

McLennan, S. M.: Rare earth elements in sedimentary rocks; influence of provenance and sedimentary processes, Rev. Mineral. Geochem., 21, 169-200, 1989.

McManus, J., Berelson, W. M., Klinkhammer, G. P., Hammond, D. E., and Holm, C.: Authigenic uranium: Relationship to oxygen penetration depth and organic carbon rain, Geochim. Cosmochim. Acta, 69, 95-108, doi:10.1016/j.gca.2004.06.023, 2005.

Meeker, L. D. and Mayewski, P. A.: A 1400-year high-resolution record of atmospheric circulation over the North Atlantic and Asia, Holocene, 12, 257-266, doi:10.1191/0959683602hl542ft, 2002.

Melki, T., Kallel, N., Jorissen, F. J., Guichard, F., Dennielou, B., Berné, S., Labeyrie, L., and Fontugne, M.: Abrupt climate change, sea surface salinity and paleoproductivity in the western Mediterranean Sea (Gulf of Lion) during the last 28 kyr, Palaeogeogr. Palaeoclimatol. Palaeoecol., 279, 96-113, doi:10.1016/j.palaeo.2009.05.005, 2009.
Millot, C.: Circulation in the Western Mediterranean Sea, J. Mar. Syst., 20, 423-442, doi:10.1016/S0924-7963(98)00078-5, 1999.

Millot, C.: Short-term variability of the Mediterranean in- and out-flows, Geophys. Res. Lett., 35, L15603, doi:10.1029/2008GL033762, 2008.

Moberg, A., Sonechkin, D. M., Holmgren, K., Datsenko, N. M., and Karlen, W.: Highly variable Northern Hemisphere temperatures reconstructed from low- and high-resolution proxy data, Nature, 433, 613-617, doi:10.1038/nature03265, 2005.

Moreno, A., Cacho, I., Canals, M., Prins, M. A., SánchezGoñi, M.-F., Grimalt, J. O., and Weltje, G. J.: Saharan dust transport and high-latitude glacial climatic variability: The Alboran Sea record, Quatern. Res., 58, 318-328, doi:10.1006/qres.2002.2383, 2002.

Moreno, A., Cacho, I., Canals, M., Grimalt, J. O., and SánchezVidal, A.: Millennial-scale variability in the productivity signal from the Alboran Sea record, Western Mediterranean Sea, Palaeogeogr. Palaeoclimatol. Palaeoecol., 211, 205-219, doi:10.1016/j.palaeo.2004.05.007, 2004.

Moreno, A., Cacho, I., Canals, M., Grimalt, J. O., Sánchez-Goñi, M. F., Shackleton, N., and Sierro, F. J.: Links between marine and atmospheric processes oscillating on a millennial time-scale, A multi-proxy study of the last 50,000 yr from the Alboran Sea (Western Mediterranean Sea), Quaternary Sci. Rev., 24, 16231636, doi:10.1016/j.quascirev.2004.06.018, 2005.

Moreno, A., Pérez, A., Frigola, J., Nieto-Moreno, V., RodrigoGámiz, M., González-Sampériz, P., Morellón, M., MartínPuertas, C., Corella, J. P., Belmonte, A., Sancho, C., Cacho, I., Herrera, G., Canals, M., Jiménez-Espejo, F., Martínez Ruiz, F., Vegas, T., and Valero-Garcés, B. L.: The Medieval Climate Anomaly in the Iberian Peninsula reconstructed from a compilation of marine and lake records, under review, 2011.

Moulin, C., Lambert, C. E., Dulac, F., and Dayan, U.: Control of atmospheric export of dust from North Africa by the North Atlantic Oscillation, Nature, 387, 691-694, doi:10.1038/42679, 1997.

O’Brien, S. R., Mayewski, P. A., Meeker, L. D., Meese, D. A., Twickler, M. S., and Whitlow, S. I.: Complexity of Holocene climate as reconstructed from a Greenland ice core, Science, 270, 1962-1964, doi:10.1126/science.270.5244.1962, 1995.

Oksanen, J., Kindt, R., Legendre, P., O'Hara, B., Simpson, G. L., Solymos, P., Stevens, M. H. H., and Wagner, H.: Vegan: Community Ecology Package, available at: http://cran.r-project. org/web/packages/vegan/index.html (last access: January 2011), R package version 1.15-4, 2009.

Perkins, H., Kinder, T., and Violette, P. L.: The Atlantic inflow in the Western Alboran Sea, J. Phys. Oceanogr., 20, 242-263, 1990.

Price, N. B., Calvert, S. E., and Jones, P. G. W.: Distribution of iodine and bromine in sediments of Southwestern Barents-Sea, J. Mar. Res., 28, 22-34, 1970.

Proctor, C. J., Baker, A., Barnes, W. L., and Gilmour, M. A.: A thousand year speleothem proxy record of North Atlantic climate from Scotland, Clim. Dynam., 16, 815-820, doi:10.1007/s003820000077, 2000.

Proctor, C., Baker, A., and Barnes, W.: A three thousand year record of North Atlantic climate, Clim. Dynam., 19, 449-454, doi:10.1007/s00382-002-0236-x, 2002.

Reimer, P. J., Baillie, M. G. L., Bard, E., Bayliss, A., Beck, J. W., Blackwell, P. G., Ramsey, C. B., Buck, C. E., Burr, G. S., Edwards, R. L., Friedrich, M., Grootes, P. M., Guilderson, 
T. P., Hajdas, I., Heaton, T. J., Hogg, A. G., Hughen, K. A., Kaiser, K. F., Kromer, B., McCormac, F. G., Manning, S. W., Reimer, R. W., Richards, D. A., Southon, J. R., Talamo, S., Turney, C. S. M., van der Plicht, J., and Weyhenmeye, C. E.: INTCAL09 and MARINE09 Radiocarbon age calibration curve, 050,000 years cal BP, Radiocarbon, 51, 1111-1150, 2009.

Rimbu, N., Lohmann, G., Lorenz, S. J., Kim, J. H., and Schneider, R. R.: Holocene climate variability as derived from alkenone sea surface temperature and coupled ocean-atmosphere model experiments, Clim. Dynam., 23, 215-227, doi:10.1007/s00382-0040435-8, 2004.

Rogerson, M., Cacho, I., Jiménez-Espejo, F., Reguera, M. I., Sierro, F. J., Martínez-Ruiz, F., Frigola, J., and Canals, M.: A dynamic explanation for the origin of the western Mediterranean organic-rich layers, Geochem. Geophy. Geosy., 9, Q07U01, doi:10.1029/2007GC001936, 2008.

Rogerson, M., Colmenero-Hidalgo, E., Levine, R. C., Rohling, E. J., Voelker, A. H. L., Bigg, G. R., Schönfeld, J., Cacho, I., Sierro, F. J., Löwemark, L., Reguera, M. I., de Abreu, L., and Garrick, K.: Enhanced Mediterranean-Atlantic exchange during Atlantic freshening phases, Geochem. Geophy. Geosy., 11, Q08013, doi:10.1029/2009gc002931, 2010.

Rohling, E. J., Hayes, A., Mayewski, P. A., and Kucera, M.: Holocene climate variability in the Eastern Mediterranean, and the end of the Bronze Age, in: Forces of Transformation: The end of the Bronze Age in the Mediterranean, edited by: Bachhuber, C. and Roberts, R. G., BANEA Publication Series 1, Oxbow Books, Oxford, 2-5, 2009.

Sánchez-Cabeza, J., Masqué, P., and Ani-Ragolta, I.: ${ }^{210} \mathrm{~Pb}$ and ${ }^{210} \mathrm{Po}$ analysis in sediments and soils by microwave acid digestion, J. Radioanal. Nucl. Ch., 227, 19-22, doi:10.1007/bf02386425, 1998.

Sánchez-Goñi, M. F., Cacho, I., Turon, J. L., Guiot, J., Sierro, F. J., Peypouquet, J. P., Grimalt, J. O., and Shackleton, N. J.: Synchroneity between marine and terrestrial responses to millennial scale climatic variability during the last glacial period in the Mediterranean region, Clim. Dynam., 19, 95-105, doi:10.1007/s00382-001-0212-x, 2002.

Seager, R., Graham, N., Herweijer, C., Gordon, A. L., Kushnir, Y., and Cook, E.: Blueprints for Medieval hydroclimate, Quaternary Sci. Rev., 26, 2322-2336, 2007.

Shindell, D. T., Schmidt, G. A., Mann, M. E., Rind, D., and Waple, A.: Solar forcing of regional climate change during the Maunder Minimum, Science, 294, 2149-2152, doi:10.1126/science.1064363, 2001.

Sierro, F. J., Hodell, D. A., Curtis, J. H., Flores, J. A., Reguera, I., Colmenero-Hidalgo, E., Bárcena, M. A., Grimalt, J. O., Cacho, I., Frigola, J., and Canals, M.: Impact of iceberg melting on Mediterranean thermohaline circulation during Heinrich events, Paleoceanography, 20, PA2019, doi:10.1029/2004pa001051, 2005.

Stein, R., Hefter, J., Grützner, J., Voelker, A., and Naafs, B. D. A.: Variability of surface water characteristics and Heinrichlike events in the Pleistocene midlatitude North Atlantic Ocean: Biomarker and XRD records from IODP Site U1313 (MIS 169), Paleoceanography, 24, PA2203, doi:10.1029/2008pa001639, 2009.

Steinhilber, F., Beer, J., and Fröhlich, C.: Total solar irradiance during the Holocene, Geophys. Res. Lett., 36, L19704, doi:10.1029/2009g1040142, 2009.

Stuiver, M. and Reimer, P. J.: Extended C-14 database and revised Calib 3.0 C-14 age calibration program, Radiocarbon, 35, 215 230, 1993.

Sumner, G., Homar, V., and Ramis, C.: Precipitation seasonality in eastern and southern coastal Spain, Int. J. Climatol., 21, 219247, doi:10.1002/joc.600, 2001.

ten Haven, H. L., de Leeuw, J. W., Schenck, P. A., and Klaver, G. T.: Geochemistry of Mediterranean sediments, bromine/organic carbon and uranium/organic carbon ratios as indicators for different sources of input and post-depositional oxidation, respectively, Org. Geochem., 13, 255-261, doi:10.1016/01466380(88)90044-7, 1988.

Thomson, J., Mercone, D., de Lange, G. J., and van Santvoort, P. J. M.: Review of recent advances in the interpretation of eastern Mediterranean sapropel S1 from geochemical evidence, Mar. Geol., 153, 77-89, 1999.

Tribovillard, N., Algeo, T. J., Lyons, T., and Riboulleau, A.: Trace metals as paleoredox and paleoproductivity proxies: An update, Chem. Geol., 232, 12-32, doi:10.1016/j.chemgeo.2006.02.012, 2006.

Trigo, R. M., Osborn, T. J., and Corte-Real, J. M.: The North Atlantic Oscillation influence on Europe: climate impacts and associated physical mechanisms, Clim. Res., 20, 9-17, doi:10.3354/cr020009, 2002.

Trigo, R. M., Pozo-Vázquez, D., Osborn, T. J., Castro-Díez, Y., Gámiz-Fortis, S., and Esteban-Parra, M. J.: North Atlantic oscillation influence on precipitation, river flow and water resources in the Iberian Peninsula, Int. J. Climatol., 24, 925-944, doi:10.1002/joc.1048, 2004.

Trouet, V., Esper, J., Graham, N. E., Baker, A., Scourse, J. D., and Frank, D. C.: Persistent positive North Atlantic Oscillation mode dominated the Medieval Climate Anomaly, Science, 324, 78-80, doi:10.1126/science.1166349, 2009.

Turney, C. S. M. and Palmer, J. G.: Does the El Niño-Southern Oscillation control the interhemispheric radiocarbon offset?, Quatern. Res., 67, 174-180, doi:10.1016/j.yqres.2006.08.008, 2007.

van der Weijden, C. H.: Pitfalls of normalization of marine geochemical data using a common divisor, Mar. Geol., 184, 167187, doi:10.1016/S0025-3227(01)00297-3, 2002.

van Geel, B., Buurman, J., and Waterbolk, H. T.: Archaeological and palaeoecological indications of an abrupt climate change in The Netherlands, and evidence for climatological teleconnections around $2650 \mathrm{BP}$, J. Quaternary Sci., 11, 451460, doi:10.1002/(sici)1099-1417(199611/12)11:6<451::aidjqs275>3.0.co;2-9, 1996.

van Geel, B., Raspopov, O. M., Renssen, H., van der Plicht, J., Dergachev, V. A., and Meijer, H. A. J.: The role of solar forcing upon climate change, Quaternary Sci. Rev., 18, 331-338, doi:10.1016/S0277-3791(98)00088-2, 1999.

Voelker, A. H. L., Lebreiro, S. M., Schönfeld, J., Cacho, I., Erlenkeuser, H., and Abrantes, F.: Mediterranean outflow strengthening during northern hemisphere coolings: A salt source for the glacial Atlantic?, Earth Planet. Sc. Lett., 245, 39-55, doi:10.1016/j.eps1.2006.03.014, 2006.

Wanner, H., Bronnimann, S., Casty, C., Gyalistras, D., Luterbacher, J., Schmutz, C., Stephenson, D. B., and Xoplaki, E.: North Atlantic Oscillation - Concepts and studies, Surv. Geophys., 22 , 
321-382, 2001.

Wanner, H., Beer, J., Bütikofer, J., Crowley, T. J., Cubasch, U., Flückiger, J., Goosse, H., Grosjean, M., Joos, F., Kaplan, J. O., Küttel, M., Müller, S. A., Prentice, I. C., Solomina, O., Stocker, T. F., Tarasov, P., Wagner, M., and Widmann, M.: Mid- to Late Holocene climate change: an overview, Quaternary Sci. Rev., 27, 1791-1828, doi:10.1016/j.quascirev.2008.06.013, 2008.

Weldeab, S., Siebel, W., Wehausen, R., Emeis, K.-C., Schmiedl, G., and Hemleben, C.: Late Pleistocene sedimentation in the Western Mediterranean Sea: implications for productivity changes and climatic conditions in the catchment areas, Palaeogeogr. Palaeoclimatol. Palaeoecol., 190, 121-137, 2003.
Willard, D. A., Bernhardt, C. E., Korejwo, D. A., and Meyers, S. R.: Impact of millennial-scale Holocene climate variability on eastern North American terrestrial ecosystems: pollenbased climatic reconstruction, Global Planet. Change, 47, 17-35, doi:10.1016/j.gloplacha.2004.11.017, 2005.

Ziegler, M., Jilbert, T., de Lange, G. J., Lourens, L. J., and Reichart, G.-J.: Bromine counts from XRF scanning as an estimate of the marine organic carbon content of sediment cores, Geochem. Geophy. Geosy., 9, Q05009, doi:10.1029/2007gc001932, 2008. 